\title{
Oak Ridge National Laboratory Current Magnitude and Frequency Response of SIPROTEC Relays
}

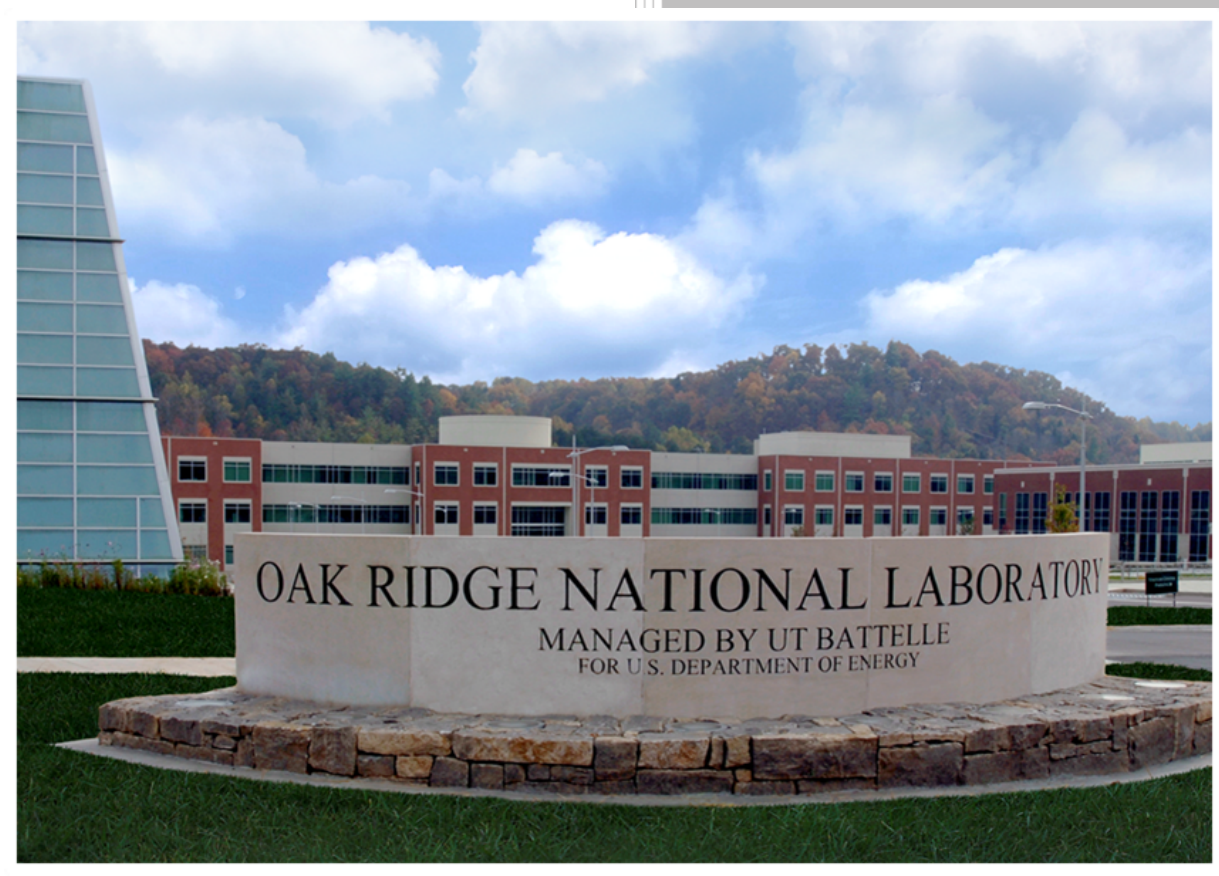

\section{Approved for public release Distribution is unlimited}

Emilio C. Piesciorovsky Thomas Karnowski

June 2020 


\section{DOCUMENT AVAILABILITY}

Reports produced after January 1, 1996, are generally available free via US Department of Energy (DOE) SciTech Connect.

Website www.osti.gov

Reports produced before January 1, 1996, may be purchased by members of the public from the following source:

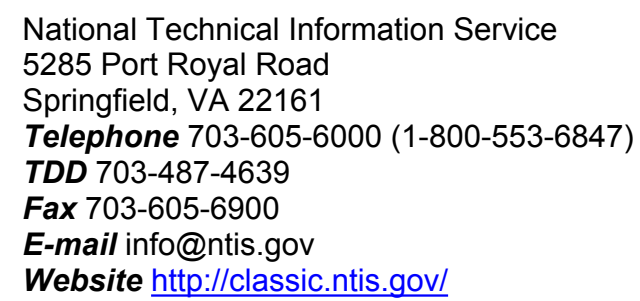

Reports are available to DOE employees, DOE contractors, Energy Technology Data Exchange representatives, and International Nuclear Information System representatives from the following source:

Office of Scientific and Technical Information

PO Box 62

Oak Ridge, TN 37831

Telephone 865-576-8401

Fax 865-576-5728

E-mail reports@osti.gov

Website http://www.osti.gov/contact.html

This report was prepared as an account of work sponsored by an agency of the United States Government. Neither the United States Government nor any agency thereof, nor any of their employees, makes any warranty, express or implied, or assumes any legal liability or responsibility for the accuracy, completeness, or usefulness of any information, apparatus, product, or process disclosed, or represents that its use would not infringe privately owned rights. Reference herein to any specific commercial product, process, or service by trade name, trademark, manufacturer, or otherwise, does not necessarily constitute or imply its endorsement, recommendation, or favoring by the United States Government or any agency thereof. The views and opinions of authors expressed herein do not necessarily state or reflect those of the United States Government or any agency thereof. 
Electrical and Electronics Systems Research Division

OAK RIDGE NATIONAL LABORATORY

\title{
CURRENT MAGNITUDE AND FREQUENCY RESPONSE OF SIPROTEC RELAYS
}

\author{
Emilio C. Piesciorovsky \\ Thomas Karnowski
}

June 2020

\author{
Prepared by \\ OAK RIDGE NATIONAL LABORATORY \\ Oak Ridge, TN 37831-6283 \\ managed by \\ UT-BATTELLE, LLC \\ for the \\ US DEPARTMENT OF ENERGY \\ under contract DE-AC05-00OR22725
}





\section{CONTENTS}

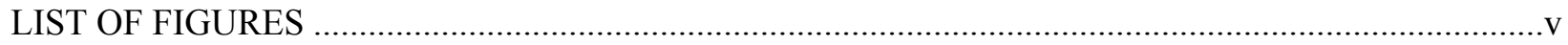

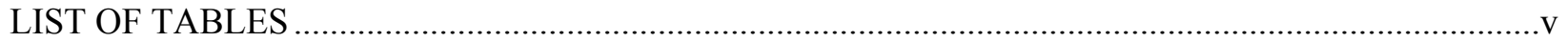

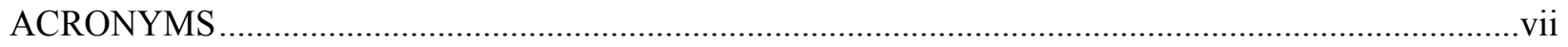

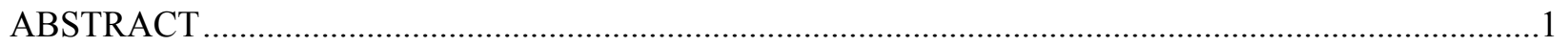

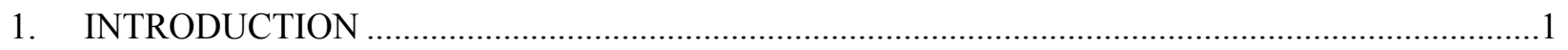

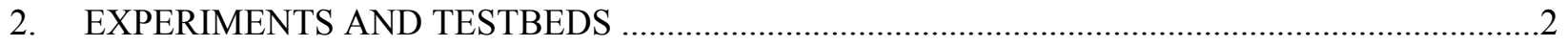

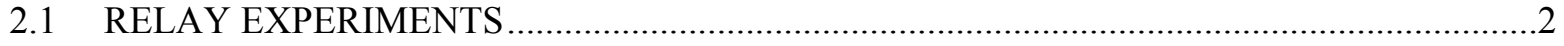

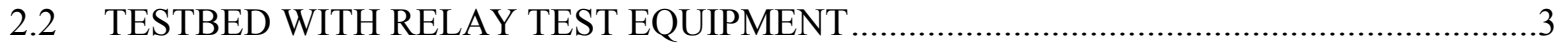

2.3 TESTBED WITH RELAY TEST EQUIPMENT AND HIGH-FREQUENCY POWER

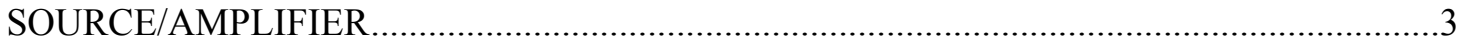

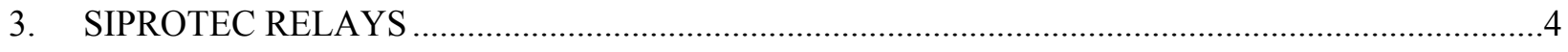

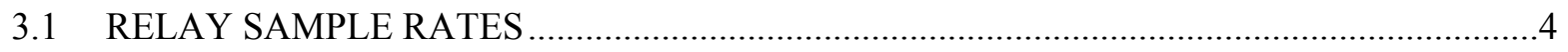

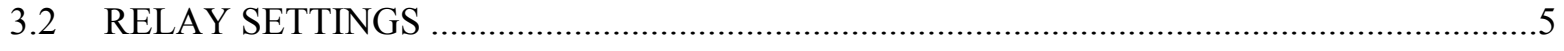

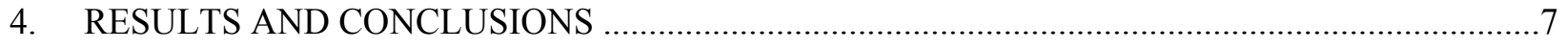

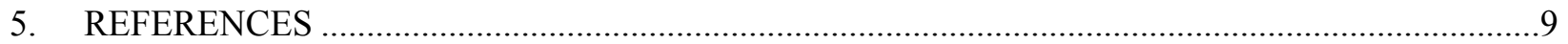

APPENDIX A. CURRENT FREQUENCY ANALYSIS UP TO 1 kHZ ..........................................

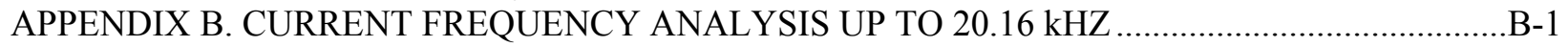

APPENDIX C. CURRENT MAGNITUDE ANALYSIS UP TO 1 kHZ ................................................

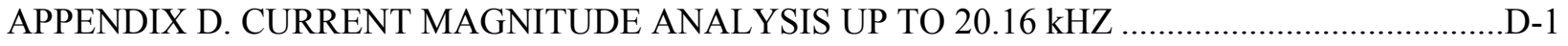

APPENDIX E. CURRENT MAGNITUDE INTENSITY FROM 1 TO 20.16 kHZ ................................ 



\section{LIST OF FIGURES}

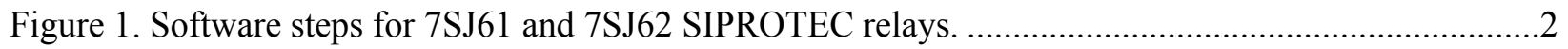

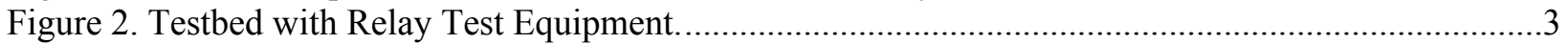

Figure 3. Testbed with Relay Test Equipment and High-Frequency Power Source/ Amplifier. .................4

Figure 4. Record events and sample rates for 7SJ61 (A) and 7SJ62 (B) SIPROTEC relays. ......................5

Figure 5. Definite-time overcurrent setting curve (A) and relays' displays (B).......................................6

Figure A.1. Measured frequency of 7SJ61 SIPROTEC relay. .................................................................

Figure A.2. Measured frequency of 7SJ62 SIPROTEC relay. .............................................................

Figure A.3. Measured frequency versus alias frequency of 7SJ61 SIPROTEC relay.............................A-1

Figure A.4. Measured frequency versus alias frequency of 7SJ62 SIPROTEC relay..............................-2

Figure A.5. Percentage error of frequency response of 7SJ61 SIPROTEC relay. ....................................

Figure A.6. Percentage error of frequency response of 7SJ62 SIPROTEC relay. ..................................-2

Figure B.1. Measured frequency versus real (source) frequency of 7SJ61 SIPROTEC relay.....................-1

Figure B.2. Measured frequency versus real (source) frequency of 7SJ62 SIPROTEC relay...................B-1

Figure B.3. Measured frequency versus alias frequency of 7SJ61 SIPROTEC relay. ...............................1

Figure B.4. Measured frequency versus alias frequency of 7SJ62 SIPROTEC relay..............................2

Figure C.1. Measured current magnitude at 0.5 (A) and 0.1 (B) Arms of 7SJ61 SIPROTEC relay.........C-1

Figure C.2. Measured current magnitude at 0.5 (A) and 0.1 (B) Arms of 7SJ62 SIPROTEC relay.........C-1

Figure C.3. Percentage error of current magnitude of 7SJ61 (A) and 7SJ62 (B) SIPROTEC relays........C-2

Figure D.1. Measured current magnitude at 0.5 (A) and 0.1 (B) Arms of 7SJ61 SIPROTEC relay.........D-1

Figure D.2. Measured current magnitude at 0.5 (A) and 0.1 (B) Arms of 7SJ62 SIPROTEC relay.........D-1

Figure E.1. Current magnitude intensity response of 7SJ61 (A) and 7SJ62 (B) SIPROTEC relays.........E-1

\section{LIST OF TABLES}

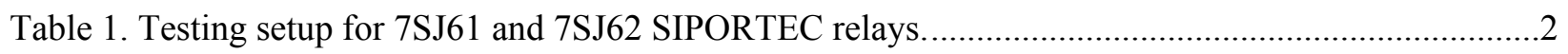

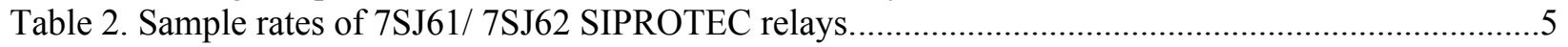

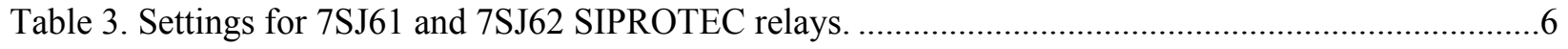

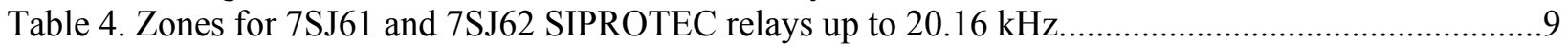





\section{ACRONYMS}

$\begin{array}{ll}\text { AC } & \text { Alternate Current } \\ \text { CT } & \text { Current Transformer } \\ \text { DC } & \text { Direct Current } \\ \text { HFPS/A } & \text { High Frequency Power Source/ Amplifier } \\ \text { HV } & \text { High Voltage } \\ \text { NE } & \text { Number of Events } \\ \text { NT } & \text { Number of Tests } \\ \text { RMS } & \text { Root Mean Square } \\ \text { RTE } & \text { Relay Test Equipment } \\ \text { SR } & \text { Sample Rate }\end{array}$





\begin{abstract}
This project examined the current magnitude and frequency response of 7SJ61 and 7SJ62 SIPROTEC relays. The measured sample frequencies for the 7SJ61 and 7SJS62 relays were 800 and $960 \mathrm{~Hz}$, respectively. The relays were tested at frequencies of up to 1 and $20.16 \mathrm{kHz}$. Two experiments were run in a lab environment. The first experiment was run at frequencies of up to $1 \mathrm{kHz}$ every $10 \mathrm{~Hz}$. The second one was run at frequencies of up to $20.16 \mathrm{kHz}$ every 200 and $240 \mathrm{~Hz}$ (common factors of sample rate frequency) for the 7SJ61 and 7SJ62 SIPROTEC relays, respectively. Both experiments were set at a current magnitude of 0.1 and 0.5 Arms.

A testbed with a Relay Test Equipment (RTE) was set to run the experiment at frequencies of up to $1 \mathrm{kHz}$, while a testbed with a RTE and High Frequency Power Source/ Amplifier (HFPS/A) was set to run at frequencies of up to $20.16 \mathrm{kHz}$. Currents of 0.1 and 0.5 Arms at different frequencies were connected at Phase A of the relays, and a current of 1 Arms $(60 \mathrm{~Hz})$ was connected at Phase B of relays. The 1 Arms current allowed the relays to trip and saved their record events by setting both relays at a definite-time overcurrent protection function. The record events were collected after the 7SJ61 and 7SJ62 relays tripped, and the current magnitude and frequency were plotted. The record events from the relays were collected using the DIGSI ${ }^{\circledR} 4$ software. The SYNCHROWAVE ${ }^{\circledR}$ Event and MATLAB ${ }^{\circledR}$ software were then used to plot the current magnitude and frequency, respectively, from the relay record events. The current magnitude and frequency were plotted at time and frequency domain, respectively.

The 7SJ61 and 7SJ62 relays measured source frequencies of up to 400 and $480 \mathrm{~Hz}$, respectively. The percentage error of frequency for the relays increased after 400 and $480 \mathrm{~Hz}$, respectively. The 7SJ62 relay with 0.1 and 0.5 Arms measured the alias frequency up to $1440 \mathrm{~Hz}$. The 7SJ61 relay with 0.1 and 0.5 Arms measured the alias frequency up to 1000 and $1200 \mathrm{~Hz}$, respectively. At frequencies higher than the alias frequency, the relays measured a DC amplitude current instead of an AC amplitude current. In the DC amplitude current zone, non-desired frequencies were measured by both relays. The current magnitude intensity (dB) for the 7SJ61 and 7SJ62 relays from 1 to $20.16 \mathrm{kHz}$ were plotted. The current magnitude intensity for the 7SJ61 relay decreased up to 2600 and $1200 \mathrm{~Hz}$ for 0.5 and 0.1 Arms tests, respectively. However, the current magnitude intensity for the 7SJ62 relay decreased up to 4800 and 2640 $\mathrm{Hz}$ for 0.5 and 0.1 Arms tests, respectively. The current magnitude and frequency response study for the 7SJ61 and 7SJ62 relays was performed satisfactorily, observing the source, alias, and non-desired measured frequency zones for both relays.
\end{abstract}

\title{
1. INTRODUCTION
}

In this project, the current magnitude and frequency response of the 7S61 and 7SJ62 relays were tested to observe the behavior of different frequency signals. The test framework was based on generating 0.1 and 0.5 Arms sinusoidal currents at frequencies of up to $20.16 \mathrm{kHz}$. The current magnitude and frequency response from these relays were collected and plotted. The states for the analog signals (current magnitude and frequency) were generated with a RTE and HFPS/A. Protection Suite ${ }^{\circledR}$ and DIGSI ${ }^{\circledR} 4$ software were used to set the test states and relays, respectively. After running the tests, the record events from the relays were collected using DIGSI 4 software. The SYNCHROWAVE Event and MATLAB software were then used to plot the current magnitude and frequency from the relay record events, respectively. Figure 1 shows the software steps for the 7SJ61 and 7SJ62 relays. 


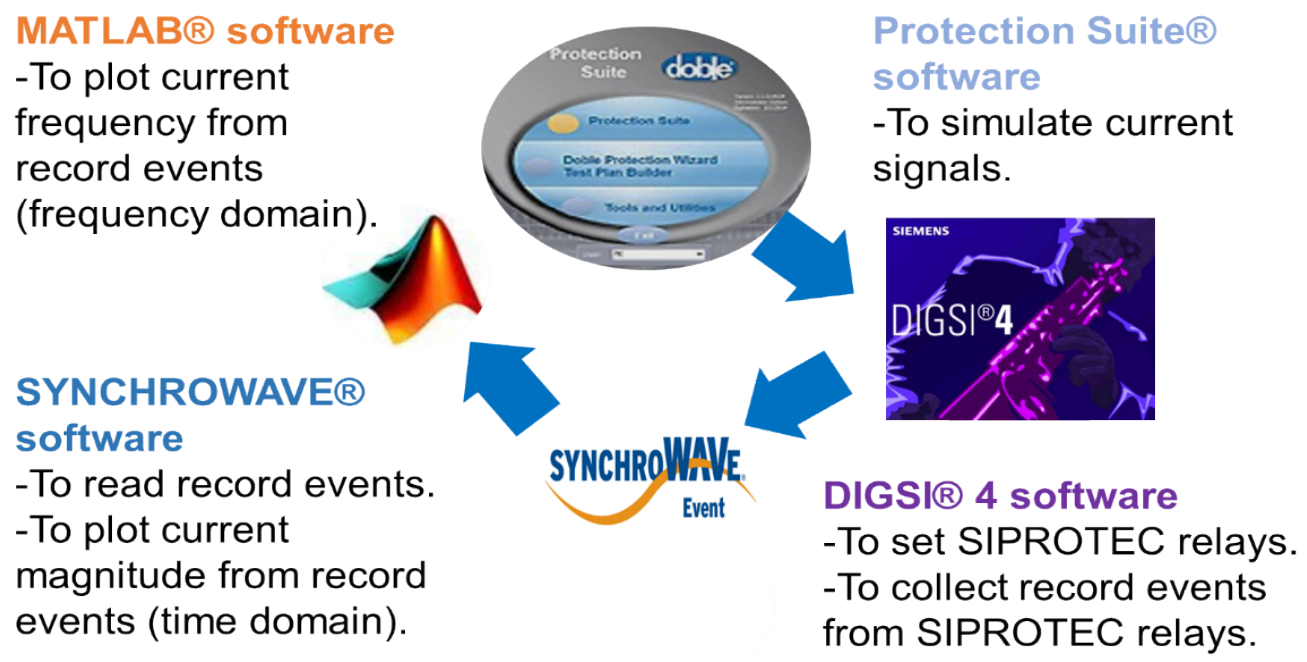

Figure 1. Software steps for 7SJ61 and 7SJ62 SIPROTEC relays.

\section{EXPERIMENTS AND TESTBEDS}

\subsection{RELAY EXPERIMENTS}

The technical approach to testing the relays was based on collecting the current frequency and magnitude at up to 1 and $20.16 \mathrm{kHz}$ for the 7SJ61 and 7SJ62 relays. The relays were tested for sinusoidal currents at different frequency signals using two testbeds. Table 1 shows the experimental setup for the 7SJ61 and 7 SJ62 relays.

Table 1. Testing setup for 7SJ61 and 7SJ62 SIPORTEC relays.

\begin{tabular}{|c|c|c|c|c|c|c|}
\hline \multicolumn{3}{|c|}{ Experiments } & \multicolumn{2}{|c|}{$\begin{array}{c}\text { Up to } 1 \mathrm{kHz} \\
(\text { From } 1 \text { to } 1000 \mathrm{~Hz})\end{array}$} & \multicolumn{2}{|c|}{$\begin{array}{c}\text { Up to } 20.16 \mathrm{kHz} \\
\text { (From } 0.96 \text { to } 20.16 \mathrm{kHz} \text { ) }\end{array}$} \\
\hline \multicolumn{3}{|c|}{ Testbeds } & \multicolumn{2}{|c|}{ with $^{\text {RTE }^{\mathrm{a}}}$} & \multicolumn{2}{|c|}{ with RTE $^{a}$ and HFPS/A } \\
\hline \multirow{4}{*}{ 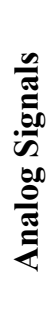 } & \multirow{2}{*}{$\begin{array}{c}\text { Phase } \\
\text { A }\end{array}$} & Frequency & \multicolumn{2}{|c|}{ Tests every $10 \mathrm{~Hz}$} & \multicolumn{2}{|c|}{$\begin{array}{l}\text { Tests performed every } 200^{\mathrm{c}} \text { and } 240^{\mathrm{c}} \mathrm{Hz} \\
\text { for } 7 \mathrm{SJ} 61 \text { and } 7 \mathrm{SJ} 62 \text { relay, respectively. }\end{array}$} \\
\hline & & RMS Current & $0.1 / 0.5$ Arms & $0.1 / 0.5$ Arms & $0.1 / 0.5$ Arms & $0.1 / 0.5$ Arms \\
\hline & \multirow{2}{*}{$\begin{array}{l}\text { Phase } \\
\text { B }\end{array}$} & Frequency & $60 \mathrm{~Hz}$ & $60 \mathrm{~Hz}$ & $60 \mathrm{~Hz}$ & $60 \mathrm{~Hz}$ \\
\hline & & RMS Current & 1 Arms & 1 Arms & 1 Arms & 1 Arms \\
\hline \multicolumn{2}{|c|}{ Relays } & SIPROTEC Model & 7SJ61 & 7SJ62 & 7SJ61 & 7SJ62 \\
\hline \multirow{2}{*}{\multicolumn{2}{|c|}{ Tests }} & $\mathrm{N}^{0}$ of Events (NE) & 202 events & 202 events & 192 events & 162 events \\
\hline & & $\begin{array}{c}\mathrm{N}^{0} \text { of tests } \\
\left(\mathrm{NT}=\sum \mathrm{NE}\right)\end{array}$ & \multicolumn{2}{|c|}{404 tests } & \multicolumn{2}{|c|}{354 tests } \\
\hline
\end{tabular}

a Relay Test Equipment (RTE)

${ }^{\mathrm{b}}$ High Frequency Power Source/ Amplifier (HFPS/A)

${ }^{\mathrm{c}}$ Common factors of relay sample rate frequency (800 and 960 samples/sec for 7SJ61 and 7SJ62 SIPROTEC relays, respectively) 
The first testbed was run with a RTE that performed simulations up to $1 \mathrm{kHz}$. The second testbed added a HFPS/A that performed current simulations of up to $20.16 \mathrm{kHz}$. In the RTE testbed, a sinusoidal current of 0.5 and 0.1 Arms was simulated at $1,10,20,30$, up to $1000 \mathrm{~Hz}$. However, the testbed with the RTE and HFPS/A simulated a sinusoidal current of 0.5 and 0.1 Arms up to $20.16 \mathrm{kHz}$. The measured sample frequencies for the 7SJ61 and 7SJS62 relays were 800 and $960 \mathrm{~Hz}$, respectively. Therefore, tests up to $20.16 \mathrm{kHz}$ were performed at 200 and $240 \mathrm{~Hz}$ (common factors of sample rate frequency) for the 7SJ61 and 7SJ62 relays, respectively. Currents of 0.1 and 0.5 Arms were set at phase A of the relays, and a current of 1 Arms $(60 \mathrm{~Hz})$ was set at phase B of the relays. The current of $1 \mathrm{Arms}(60 \mathrm{~Hz})$ allowed the relays to trip and saved their record events. The experiment up to $1 \mathrm{kHz}$ had 404 tests. However, the experiment up to $20.16 \mathrm{kHz}$ had 354 tests.

\subsection{TESTBED WITH RELAY TEST EQUIPMENT}

The testbed with the RTE performed the experiment up to $1 \mathrm{kHz}$. The Doble ${ }^{\circledR}$ F6150 was used as RTE, and it simulated the currents from 1 to $1000 \mathrm{~Hz}$. The 7S61 and 7SJ62 relays were tested at 0.1 and 0.5 Arms. The testbed with the RTE is shown in Figure 2. The Relay laptop was used to set the relays and collect the record events after the tests were run using the DIGSI 4 software. The Relay laptop was connected to a relay with a SEL C662 serial cable.

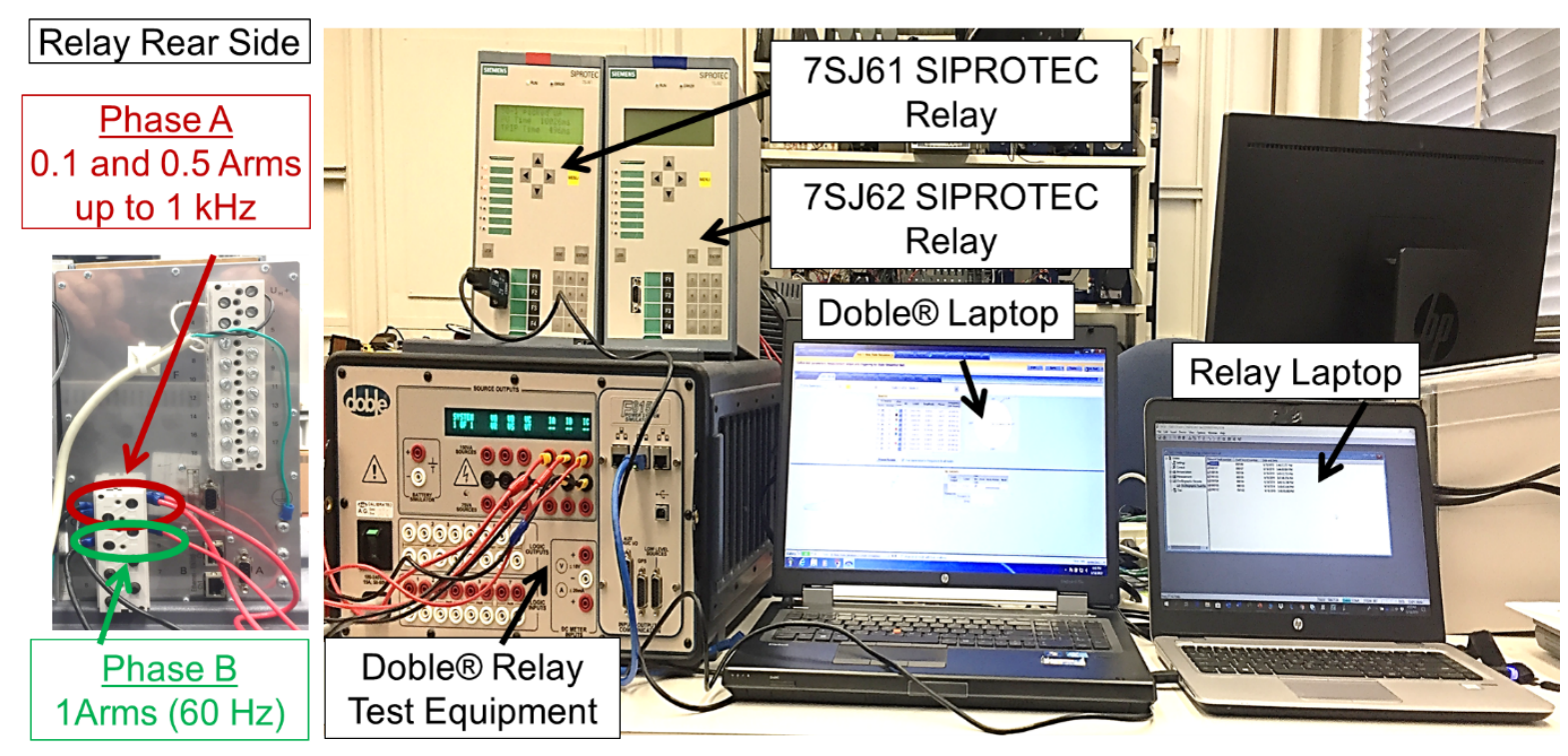

Figure 2. Testbed with Relay Test Equipment.

The Doble laptop, shown in Figure 2, was used to set the current magnitude and frequency for every test and to run the simulation. The tests were run at currents of 0.1 and 0.5 Arms at phase A of the relays. In addition, a current of $1 \mathrm{Arms}(60 \mathrm{~Hz})$ was set at phase $\mathrm{B}$ of the relays, to allow the relay to trip. The relay's record events were saved. The tests were run in groups of seven and eight tests for the 7SJ61 and 7SJ62 relays, respectively (maximum number of saved record events for these relays). Once the test group was run for every relay, the record events were collected to prevent loss of stored data.

\subsection{TESTBED WITH RELAY TEST EQUIPMENT AND HIGH-FREQUENCY POWER SOURCE/AMPLIFIER}

The testbed with the RTE (Doble F6150), high-frequency voltage source (Agilent ${ }^{\circledR} 33522 \mathrm{~A}$ ), and voltage-current power amplifier (KEPCO $\left.{ }^{\circledR}\right)$ performed the experiment up to $20.16 \mathrm{kHz}$. Figure 3 shows the Testbed with RTE and HFPS/A. The Relay laptop was used to set the relays and collect the records 
events after the test were run using the DIGSI 4 software. The Relay laptop was connected to a relay with a SEL C662 serial cable. The Doble laptop set the current magnitude and frequency for the tests and the simulations. In this testbed, the RTE generated a current of 1 Arms $(60 \mathrm{~Hz})$ to trip the relays. On the other hand, the HFPS/A generated currents of 0.1 and 0.5 Arms up to $20.16 \mathrm{kHz}$.
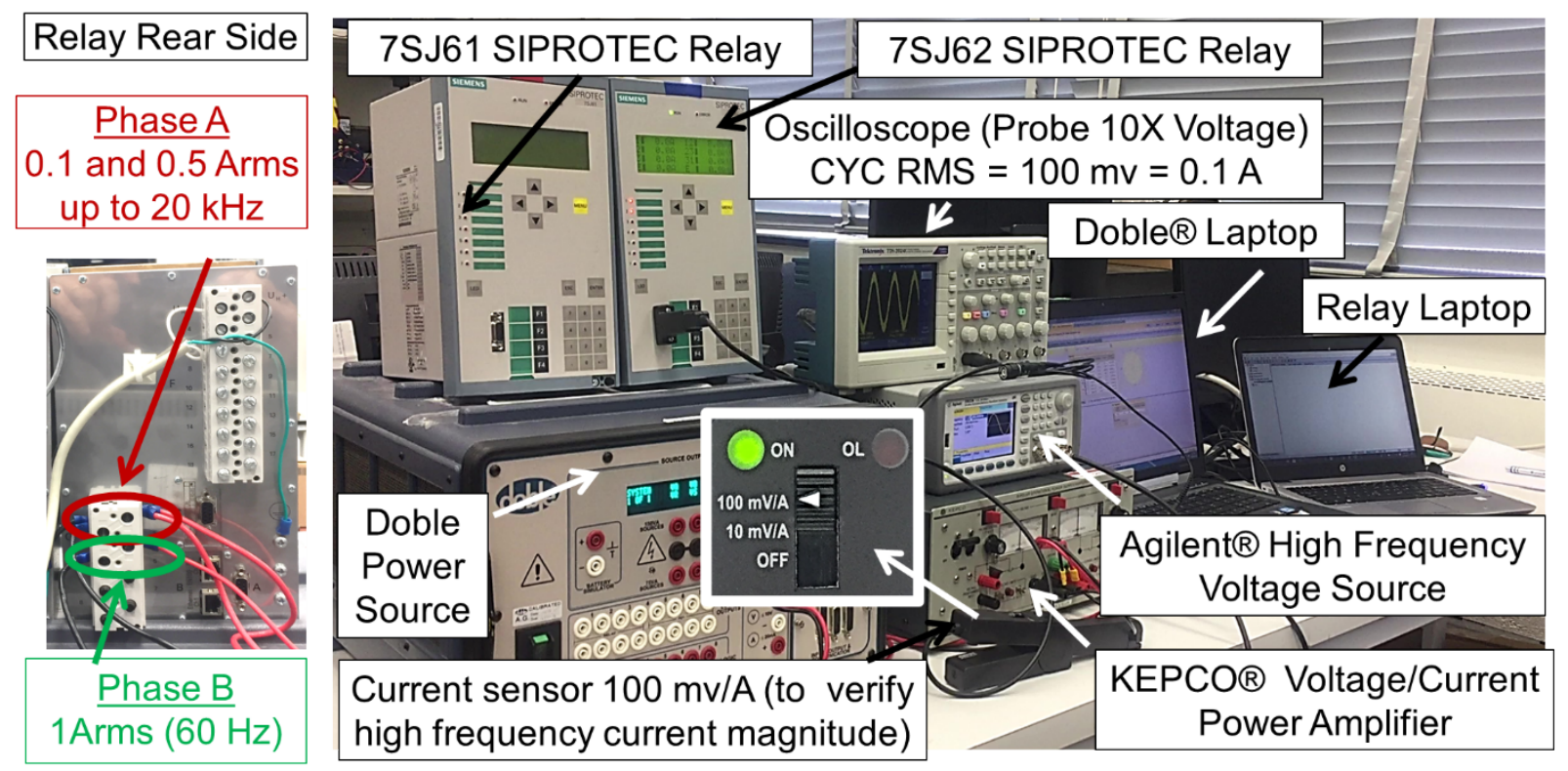

Figure 3. Testbed with Relay Test Equipment and High-Frequency Power Source/ Amplifier.

In Figure 3, the high-frequency voltage source was connected to the voltage/current power amplifier. Then, the high-frequency currents were generated by setting a sinusoidal voltage (up to $20.16 \mathrm{kHz}$ ). The sinusoidal voltage was converted into a sinusoidal current by the voltage/current power amplifier that was connected to the relay (Phase A). To verify currents of 0.1 or 0.5 Arms for the relay tests, a clamp current sensor scaled at $100 \mathrm{mv} / \mathrm{A}$ was connected to an oscilloscope with a Probe 10x Voltage, measuring 100 and $500 \mathrm{mV}$ (RMS cycle voltages on the oscilloscope) for the 0.1 and 0.5 Arms current tests, respectively.

\section{SIPROTEC RELAYS}

\subsection{RELAY SAMPLE RATES}

The sample rate (SR) is defined as the speed at which samples are taken by the data acquisition units of measurement devices. The SR is measured in "samples per second," and it is usually expressed in Hertz $(\mathrm{Hz})$, which means a collection of one data point per second. In relays, the data acquisition unit is the basic building block that collects the data points with a stamped time. In these devices, the data acquisition unit computes the voltage and current phasors from analog voltage and current waveforms. Based on a publication [1], the SR for the 7SJ61 and 7SJ62 SIPROTEC relays should be $800 \mathrm{~Hz}$.

However, the 7SJ62 SIPROTEC relay instruction manual [2] reported a SR of $960 \mathrm{~Hz}$. To validate the SR for the 7SJ61 and 7SJ62 relays, a sinusoidal current $(60 \mathrm{~Hz})$ with the RTE (Doble F6150) was generated and injected to the relays. Then, the record events were collected and plotted to find the measured sample rate for both relays. Figure 4.A-B shows the record event and sample rate for the 7SJ61 and 7SJ62 relays, respectively. The record events validated a sample rate of 800 and $960 \mathrm{~Hz}$ for the 7SJ61 and 7SJ62 relays, respectively. Table 2 shows the sample rates for the relays. 

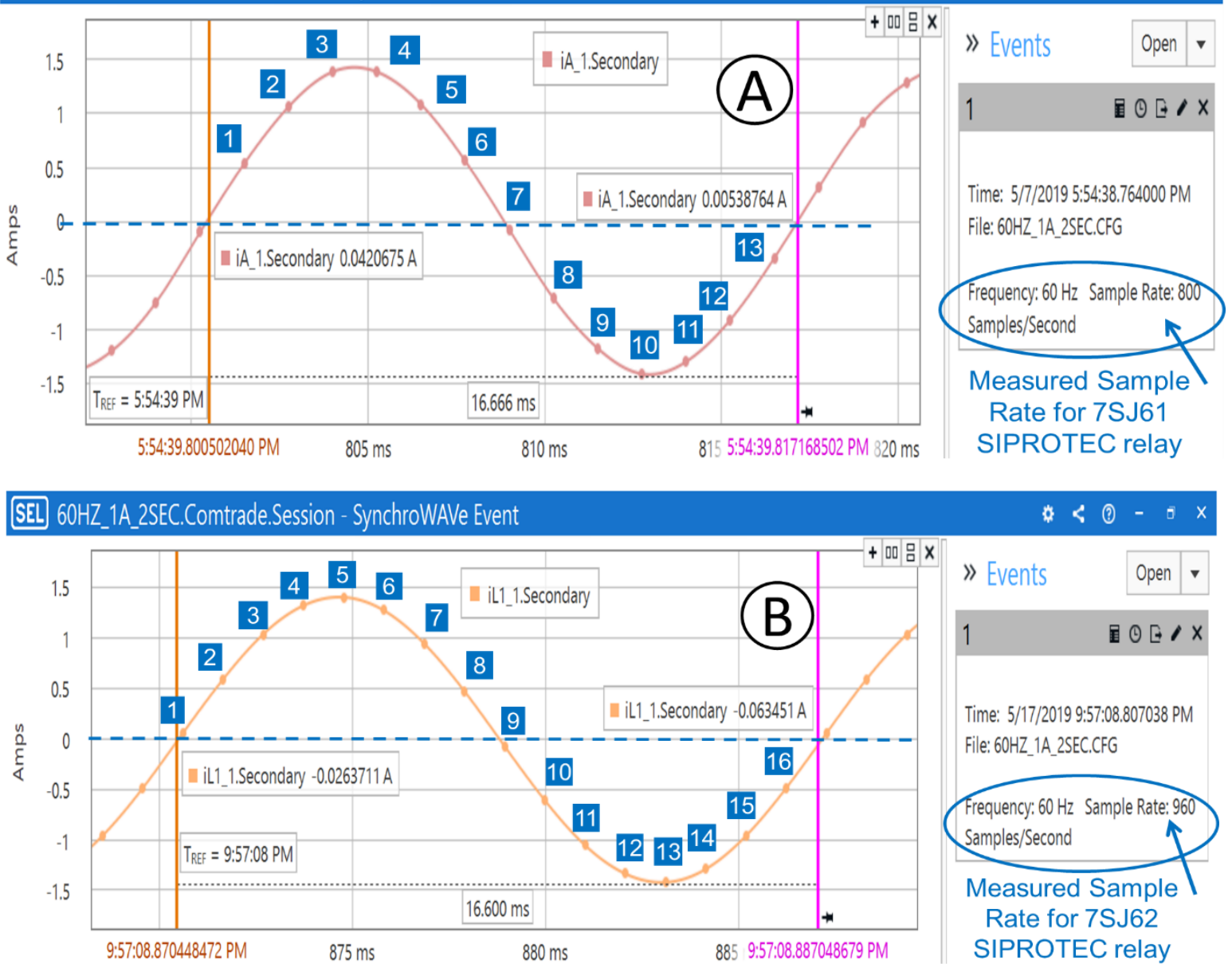

Figure 4. Record events and sample rates for 7SJ61 (A) and 7SJ62 (B) SIPROTEC relays.

Table 2. Sample rates of 7SJ61/ 7SJ62 SIPROTEC relays.

\begin{tabular}{|c|c|c|c|}
\hline \multirow{2}{*}{$\begin{array}{l}\text { Relay } \\
\text { Model }\end{array}$} & \multicolumn{2}{|c|}{ Sample rate from literature review $[\mathrm{Hz}]$} & \multirow{2}{*}{$\begin{array}{l}\text { Measured sample rate from record events } \\
{[\mathrm{Hz}]}\end{array}$} \\
\hline & & & \\
\hline 7SJ61 & $800^{a}$ & $-\quad b$ & 800 \\
\hline 7SJ62 & $800^{a}$ & $960^{b}$ & 960 \\
\hline
\end{tabular}

${ }^{a}$ HV Power Measurements \& Protection Ltd.

b SIPROTEC ${ }^{\circledR}$ Multi-Functional Protective Relay with Local Control 7SJ62/63/64 (V4.6) manual.

\subsection{RELAY SETTINGS}

The 7SJ61 and 7SJ62 relay settings are shown in Table 3. In the "Power System Data 1" function, the rated frequency and current transformer (CT) rated primary/secondary currents were set on the relays. However, the time delay and pickup for the 50-1 and 50-2 elements were set in the "Setting Group A," and the record event was set at the set "Oscillographic Fault Records." 
Table 3. Settings for 7SJ61 and 7SJ62 SIPROTEC relays.

\begin{tabular}{|c|c|c|c|c|}
\hline \multirow{2}{*}{ Functions } & \multirow{2}{*}{ Settings } & \multirow{2}{*}{ Descriptions } & \multicolumn{2}{|c|}{ Values of SIPROTEC Relays } \\
\hline & & & 7SJ61 & 7SJ62 \\
\hline \multirow{3}{*}{$\begin{array}{c}\text { Power System } \\
\text { Data } 1\end{array}$} & Power Systems & Rated Frequency & $60 \mathrm{~Hz}$ & $60 \mathrm{~Hz}$ \\
\hline & \multirow{2}{*}{ CTs } & CT Rated Primary Current & $10 \mathrm{~A}$ & $100 \mathrm{~A}$ \\
\hline & & CT Rated Secondary Current & $5 \mathrm{~A}$ & $1 \mathrm{~A}$ \\
\hline \multirow{6}{*}{$\begin{array}{l}\text { Setting } \\
\text { Group A }\end{array}$} & \multirow{6}{*}{$\begin{array}{c}50 / 51 \\
\text { Phase/Ground } \\
\text { Overcurrent } \\
\text { Protection }\end{array}$} & 50-1 Time Delay & $0.50 \mathrm{sec}$ & $0.50 \mathrm{sec}$ \\
\hline & & 50-1 Pickup & $0.50 \mathrm{~A}$ & $0.50 \mathrm{~A}$ \\
\hline & & 50-2 Time Delay & $0.00 \mathrm{sec}$ & $0.00 \mathrm{sec}$ \\
\hline & & 50-2 Pickup & $5.00 \mathrm{~A}$ & $5.00 \mathrm{~A}$ \\
\hline & & 50-3 Time Delay & $0.00 \mathrm{sec}$ & $0.00 \mathrm{sec}$ \\
\hline & & 50-3 Pickup & oo A & oo A \\
\hline \multirow{6}{*}{$\begin{array}{l}\text { Oscillographic } \\
\text { Fault Records }\end{array}$} & \multirow{6}{*}{ Osc. Fault Rec. } & Waveform Capture & Save with Pickup & Save with Pickup \\
\hline & & Scope of Waveform Data & Fault event & Fault event \\
\hline & & $\begin{array}{l}\text { Max. length of a Waveform Capture } \\
\text { Record }\end{array}$ & $2.00 \mathrm{sec}$ & $2.00 \mathrm{sec}$ \\
\hline & & Captured Waveform Prior to Triger & $0.25 \mathrm{sec}$ & $0.25 \mathrm{sec}$ \\
\hline & & Captured Waveform after Event & $0.10 \mathrm{sec}$ & $0.10 \mathrm{sec}$ \\
\hline & & Capture Time via Binary Input & $0.50 \mathrm{sec}$ & $0.50 \mathrm{sec}$ \\
\hline
\end{tabular}

The 7SJ61 and 7SJ62 relays were set with a time overcurrent protection. This function is based on the phase-selective measurement of the phase current to trip the relay in an overcurrent fault situation. The relays were set with two definite-time overcurrent protection elements for the phase currents. The current threshold and the delay time were set within a range that allowed the relays to trip during the tests and their record events to be stored. The relays were set with a 50-1 and 50-2 time delay of 0.50 and 0.00 seconds, respectively, and a 50-1 and 50-2 pickup of 0.5 and 5.00 Arms, respectively. Based on these time delay and pickup settings, the definite-time overcurrent setting curve for the relays was plotted, as shown in Figure 5-A. At the current test of 1.0 Arms, the relays tripped at 0.5 seconds (500 milliseconds). The displays for the 7SJ61 and 7SJ62 relays are shown in Figure 5-B.

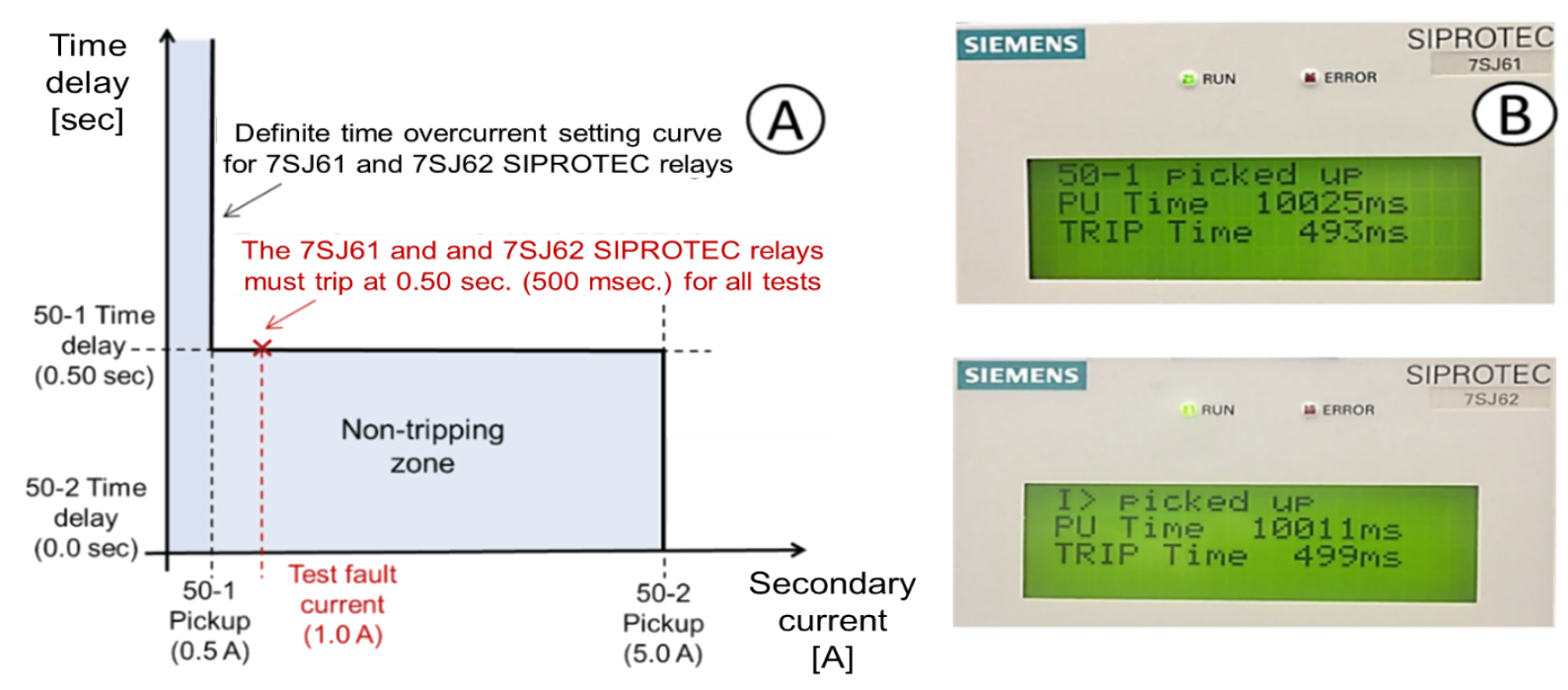

Figure 5. Definite-time overcurrent setting curve (A) and relays' displays (B). 


\section{RESULTS AND CONCLUSIONS}

The test results for 7SJ61 and 7SJ62 SIPROTEC relays were based on current magnitude and a frequency response of up to 1 and $20.16 \mathrm{kHz}$. For the first experiment, tests of up to $1 \mathrm{kHz}$ were run every $10 \mathrm{~Hz}$ for both relays. For the second experiment, tests of up to $20.16 \mathrm{kHz}$ were run every 200 and $240 \mathrm{~Hz}$ (common factors of sample rate frequency) for the 7SJ61 and 7SJ62 relays, respectively. Analyses of the frequency and current magnitude were performed in frequency and time domain, respectively. The frequency analysis was performed by plotting the phase A current from the record events. The time and frequency response of phase A current was plotted using MATLAB software. All the frequencies were then collected from the MATLAB plots, and the relay and source current frequencies were plotted and compared. On the other hand, the current magnitude analysis was performed by plotting the phase A current from the record events using SEL SYNCHROWAVE Event software. The maximum and minimum current magnitudes for all the tests were then collected, and the midpoint current magnitude was calculated, to plot and compare the measured relay current with the source current magnitude.

The frequency analysis for 7 SJ61 and 7 SJ62 relays up to $1 \mathrm{kHz}$ showed the following conclusions.

- The 7SJ61 and 7SJ62 relays measured the source frequency up to $400 \mathrm{~Hz}$ (Figure A.1) and $480 \mathrm{~Hz}$ (Figure A.2), respectively.

- $\quad$ The 7SJ61 and 7SJ62 relays generated the alias frequencies after $400 \mathrm{~Hz}$ (Figure A.3) and $480 \mathrm{~Hz}$ (Figure A.4), respectively (up to $1000 \mathrm{~Hz}$ ).

- The tests for 0.1 and 0.5 Arms showed identical frequency responses (Figure A.1-2).

- The percentage error of frequency for the 7SJ61 and 7SJ62 relays increased after 400 and $480 \mathrm{~Hz}$, respectively (Figure A.5-6). The percentage error of frequency was calculated by Equation (1).

$$
E_{\%}=\frac{f_{r}-f}{f} \times 100
$$

where $E_{\%}$ is the percentage error of frequency, $f_{r}$ is the measured relay frequency in $\mathrm{Hz}$, and $f$ is the source (real) frequency in $\mathrm{Hz}$.

- The alias frequency Equation (2), collected from a weblink [3], was validated by the relay measured frequency (Figure A.3-4).

$$
f_{a}=\left|f-\frac{(k+1) \times f_{s}}{2}\right|
$$

where $f_{a}$ is the alias frequency in $\mathrm{Hz}, f$ is the source (real) frequency in $\mathrm{Hz}, k$ is equal to 1 , and $f_{s}$ is the sampling frequency of 800 and $960 \mathrm{~Hz}$ for the 7SJ61 and 7SJ62 relays, respectively.

The frequency analysis for the 7SJ61 and 7SJ62 relays up to $20.16 \mathrm{kHz}$ led to the following conclusions.

- The 7SJ61 and 7SJ62 relays did not measure the source frequency at $\geq 1 \mathrm{kHz}$ (Figure B.1-2).

- The 7SJ61 relay with 0.1 Arms did not measure the alias frequency at $\geq 1 \mathrm{kHz}$ (Figure B.3).

- The 7SJ61 relay with 0.5 Arms measured the alias frequency up to $1.2 \mathrm{kHz}$ (Figure B.3).

- The 7SJ62 relay with 0.1 and 0.5 Arms measured the alias frequency up to $1.44 \mathrm{kHz}$ (Figure B.4). 
The current magnitude analysis for the 7SJ61 and 7SJ62 relays up to $1 \mathrm{kHz}$ led to the following conclusions.

- The measured current magnitude for 7SJ61 and 7SJ62 relays oscillated between a maximum and minimum value, current magnitude band (Figure C.1-2). Then the measured midpoint current magnitude of relay was calculated by Equation (3).

$$
I_{m p}=I_{\min }+\frac{I_{\max }-I_{\min }}{2}
$$

where $I_{m p}$ is the midpoint current magnitude of relay in Arms, $I_{\min }$ is the minimum current magnitude of relay in Arms, and $I_{\max }$ is the maximum current magnitude of relay in Arms.

- The higher the source frequency, the smaller the measured relay current magnitude for both relays (Figure C.1-2).

- The 0.5 and 0.1 Arms tests for the 7SJ61 relay showed a similar shape for the current magnitude band up to $490 \mathrm{~Hz}$ (Figure C.1).

- The 0.5 and 0.1 Arms tests for the 7SJ62 relay showed a similar shape for the current magnitude band up to $1000 \mathrm{~Hz}$ (Figure C.2).

- The percentage error of the current magnitude for 7SJ61 and 7SJ62 relays was smaller around the fundamental frequency (Figure C.3). The percentage error of current magnitude was calculated by Equation (4).

$$
E_{M \%}=\frac{I_{m p}-I_{s}}{I_{s}} \times 100
$$

where $E_{M \%}$ is the percentage error of current magnitude, $I_{m p}$ is the midpoint current magnitude of relay in Arms, and $I_{s}$ is the source (real) current magnitude in Arms.

The current magnitude analysis for the $7 S J 61$ and $7 S J 62$ relays up to $20.16 \mathrm{kHz}$ led to the following conclusions.

- The 7SJ61 relay with a source current of 0.5 and 0.1 Arms measured 0.042 and 0.018 Arms (1 kHz), respectively, decreasing to zero from 1 to $20 \mathrm{kHz}$ (Figure D.1).

- The 7SJ62 relay with a source current of 0.5 and 0.1 Arms measured 0.049 and 0.008 Arms $(0.96 \mathrm{kHz})$, respectively, decreasing to zero from 0.96 to $20.16 \mathrm{kHz}$ (Figure D.2).

The current magnitude intensity (dB) for $7 S J 61$ and $7 S J 62$ relays from 1 to $20.16 \mathrm{kHz}$ led to the following conclusions.

- $\quad$ The measured current magnitude intensity $(d B)$ for 7SJ61 and 7SJ62 relay was plotted by Equation (5).

$$
I(d B)=10 \log _{10}\left[\frac{I_{m p}}{I_{s}}\right]
$$

where $I(d B)$ is the current magnitude intensity in decibels, $I_{m p}$ is the midpoint current magnitude of the relay in Arms, and $I_{s}$ is the source (real) current magnitude in Arms. 
- The current magnitude intensity in $\mathrm{dB}$ for the 7SJ61 relay decreased up to 2600 and $1200 \mathrm{~Hz}$ for 0.5 and 0.1 Arms tests, respectively (Figure E.1-A).

- $\quad$ The current magnitude intensity in $\mathrm{dB}$ for the 7SJ62 relay decreased up to 4800 and $2640 \mathrm{~Hz}$ for 0.5 and 0.1 Arms tests, respectively (Figure E.1-B).

In conclusion, the test results for 7SJ61 and 7SJ62 SIPROTEC relays revealed an AC and DC amplitude time domain zone. Within the $\mathrm{AC}$ amplitude time domain zone, the relays measured the source and alias frequency. The 7SJ61 and 7SJ62 relays measured the source frequency up to 400 and $480 \mathrm{~Hz}$, respectively. Then, the 7SJ61 and 7SJ62 SIPROTEC relays measured the alias frequency up to 1200 and $1440 \mathrm{~Hz}$, respectively. However, within the DC amplitude time domain zone, the relays measured a nondesired frequency up to the current magnitude decreased to zero. Table 4 shows the time and frequency domain zones for 7SJ61 and 7SJ62 SIPROTEC relays up to $20.16 \mathrm{kHz}$.

Table 4. Zones for 7SJ61 and 7SJ62 SIPROTEC relays up to $20.16 \mathrm{kHz}$.

\begin{tabular}{|c|c|c|c|c|c|c|c|}
\hline \multirow{3}{*}{$\stackrel{\varrho}{\Xi}$} & \multirow{3}{*}{ 氖 } & \multicolumn{2}{|c|}{ Relay Measurements } & \multicolumn{4}{|c|}{ Source Frequency Range [R] } \\
\hline & & \multirow{2}{*}{$\begin{array}{l}\text { Frequency } \\
\text { Domain }\end{array}$} & \multirow[t]{2}{*}{$\begin{array}{l}\text { Midpoint of } \\
\text { Current Range }\end{array}$} & \multicolumn{2}{|c|}{$\begin{array}{l}\text { 7SJ61 Relay Tests } \\
\text { (Sample rate }=800 \mathrm{~Hz})\end{array}$} & \multicolumn{2}{|c|}{$\begin{array}{c}\text { 7SJ62 Relay Tests } \\
\text { a,c } \\
(\text { Sample rate }=960 \mathrm{~Hz})\end{array}$} \\
\hline & & & & 0.1 Arms & 0.5 Arms & 0.1 Arms & 0.5 Arms \\
\hline 1 & 芑 & $\begin{array}{l}=\text { source } \\
\text { frequency }\end{array}$ & $\begin{array}{l}\leq \text { source current } \\
\text { magnitude }\end{array}$ & $R \leq 400 \mathrm{~Hz}$ & $R \leq 400 \mathrm{~Hz}$ & $R \leq 480 \mathrm{~Hz}$ & $R \leq 480 \mathrm{~Hz}$ \\
\hline 2 & 《言 & $\begin{array}{l}=\text { alias } \\
\text { frequency }\end{array}$ & $\begin{array}{c}<<\text { source current } \\
\text { magnitude }\end{array}$ & $\begin{array}{c}400 \mathrm{~Hz}<R \\
\leq 1000 \mathrm{~Hz}\end{array}$ & $\begin{array}{l}400 \mathrm{~Hz}<R \\
\leq 1200 \mathrm{~Hz}\end{array}$ & $\begin{array}{c}480 \mathrm{~Hz}<R \\
\leq 1440 \mathrm{~Hz}\end{array}$ & $\begin{array}{l}480 \mathrm{~Hz}<R \\
\leq 1440 \mathrm{~Hz}\end{array}$ \\
\hline 3 & 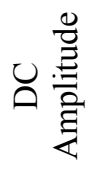 & $\begin{array}{l}\text { Non-desired } \\
\text { frequency }\end{array}$ & $\begin{array}{c}<<<\text { source } \\
\text { current } \\
\text { magnitude, } \\
\text { decreasing to zero }\end{array}$ & $\begin{array}{l}1000 \mathrm{~Hz}<R \\
\leq 20000 \mathrm{~Hz}\end{array}$ & $\begin{array}{l}1200 \mathrm{~Hz}<R \\
\leq 20000 \mathrm{~Hz}\end{array}$ & $\begin{array}{c}1440 \mathrm{~Hz}<R \\
\leq 20000 \mathrm{~Hz}\end{array}$ & $\begin{array}{c}1,440 \mathrm{~Hz}<R \\
\leq 20000 \mathrm{~Hz}\end{array}$ \\
\hline
\end{tabular}

a Tests for 7SJ61 and 7SJ62 SIPROTEC relays up to 1,000 Hz were performed every $10 \mathrm{~Hz}$.

${ }^{\mathrm{b}}$ Tests for 7SJ61 SIPROTEC relays higher than 1,000 Hz were performed every $200 \mathrm{~Hz}$.

${ }^{\mathrm{c}}$ Tests for 7SJ62 SIPROTEC relays higher than $960 \mathrm{~Hz}$ were performed every $240 \mathrm{~Hz}$.

\section{REFERENCES}

1. Event and Fault records in SIPROTEC ${ }^{\circledR}$ COMPACT and SIPROTEC $\AA 4$ relays. HV Power Measurements \& Protection Ltd., Auckland, New Zealand, P O Box 26-074. Available on 6/10/20 at http://www.hvpower.co.nz/TechnicalLibrary/Siprotec/Event_and_Fault_Records in SIPROTEC_CO MPACT_and_SIPROTEC_4_Relays.pdf

2. SIPROTEC ${ }^{\circledR}$ Multi-Functional Protective Relay with Local Control 7SJ62/63/64 (V4.6) manual. Available on 6/10/20 at http://www.automation-berlin.com/downloads/siemens/energy ptd/7SJ6264_Manual_A9_V046300_us.pdf

3. Alias Frequency Scaling Factor. Available on 6/10/20 at https://i.redd.it/3hh4sucp0ir01.png 


\section{APPENDIX A. CURRENT FREQUENCY ANALYSIS UP TO 1 kHZ}

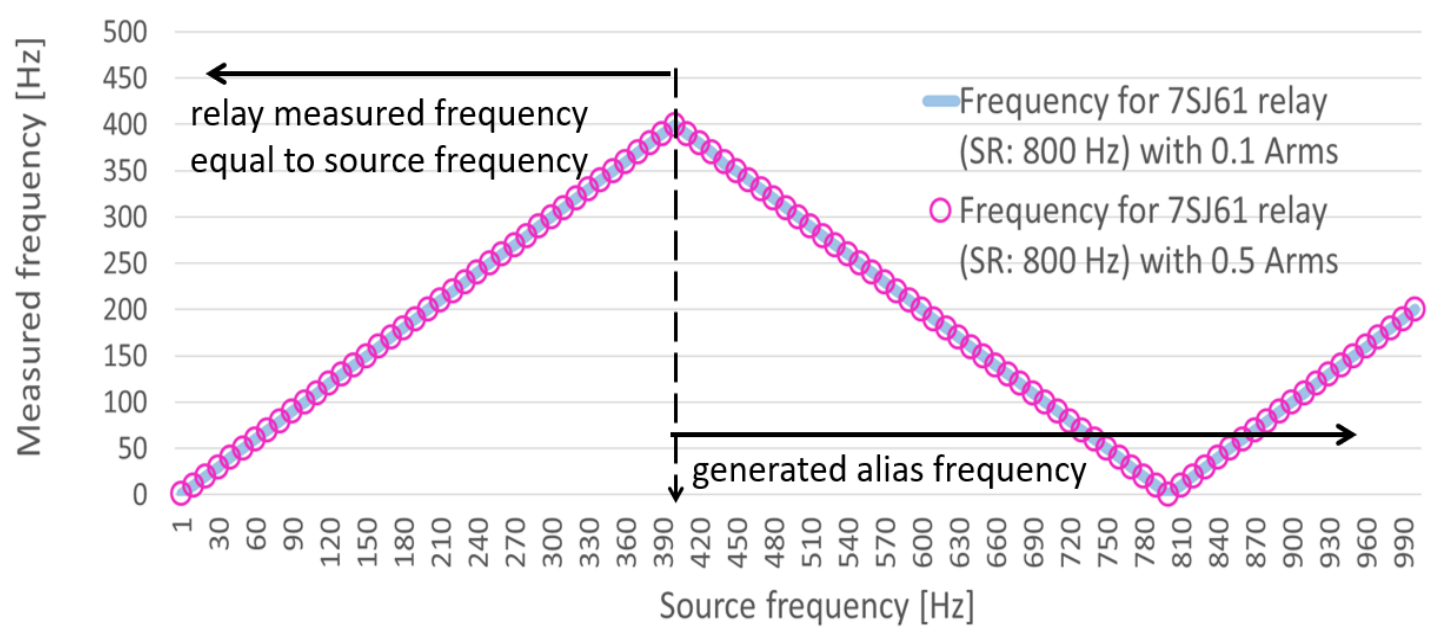

Figure A.1. Measured frequency of 7SJ61 SIPROTEC relay.

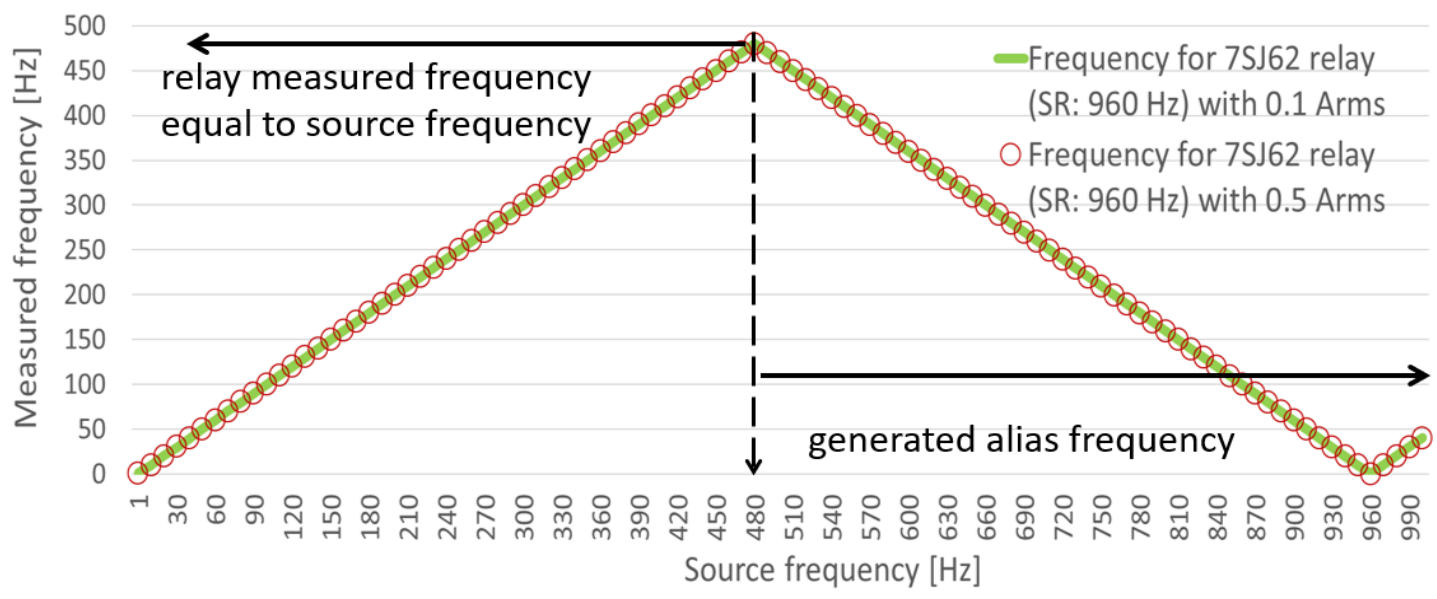

Figure A.2. Measured frequency of 7SJ62 SIPROTEC relay.

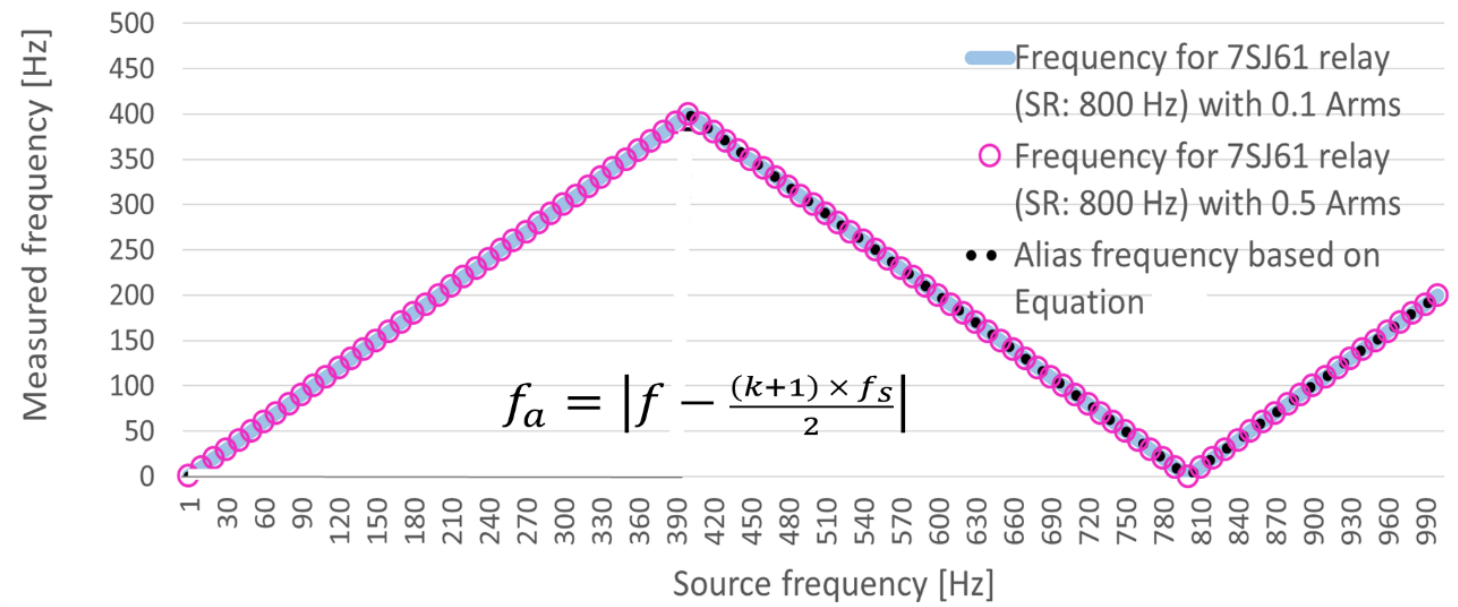

$f_{a}=$ alias frequency, $f=$ source (real) frequency, $f_{s}=$ sampling frequency $(800 \mathrm{~Hz}), k=1$

Figure A.3. Measured frequency versus alias frequency of 7SJ61 SIPROTEC relay. 


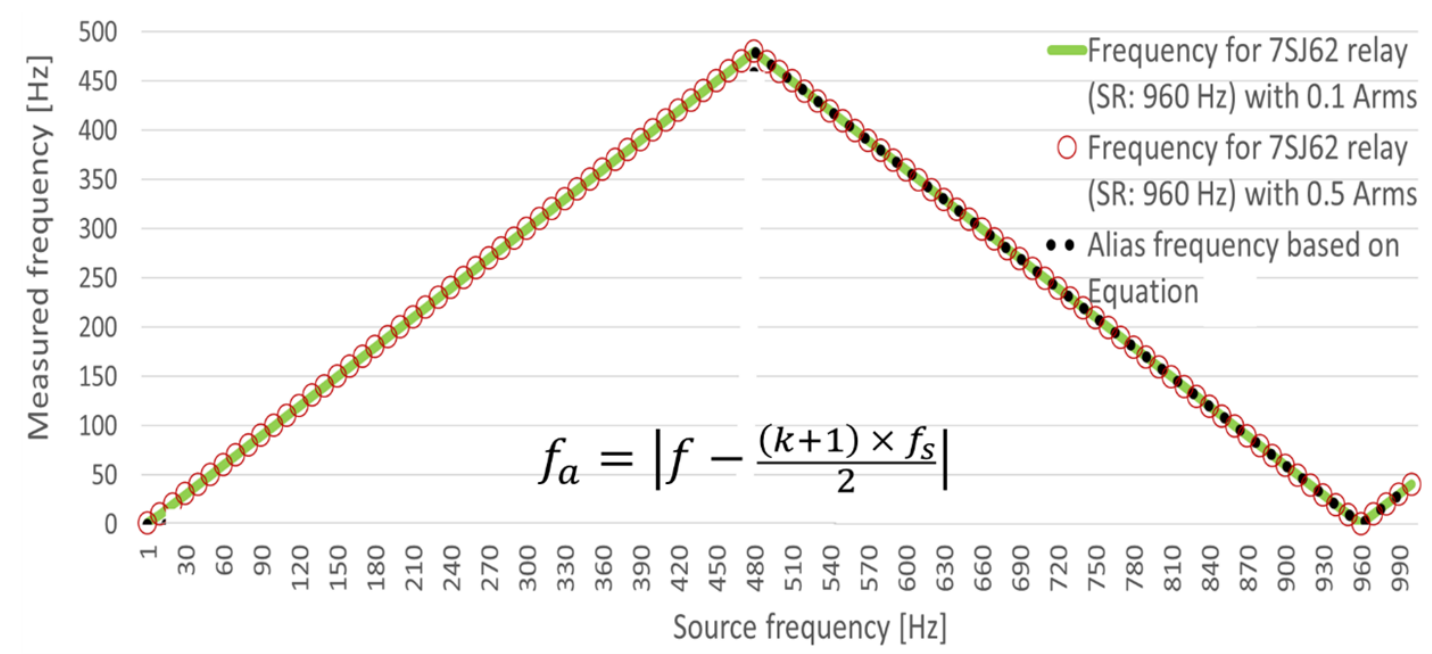

$f_{a}=$ alias frequency, $f=$ source (real) frequency, $f_{s}=$ sampling frequency $(960 \mathrm{~Hz}), k=1$

Figure A.4. Measured frequency versus alias frequency of 7SJ62 SIPROTEC relay.

Source frequency $[\mathrm{Hz}]$

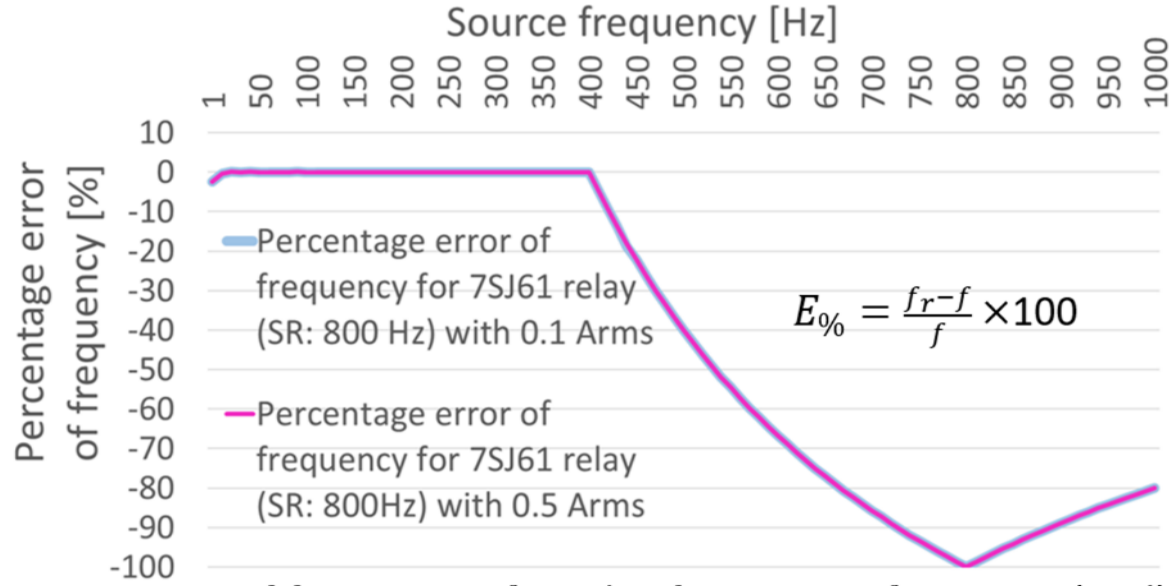

$E_{\%}=$ percentage error of frequency, $f_{r}=$ relay frequency, $f=$ source (real) frequency

Figure A.5. Percentage error of frequency response of 7SJ61 SIPROTEC relay.

Source frequency $[\mathrm{Hz}]$

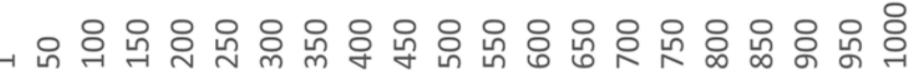

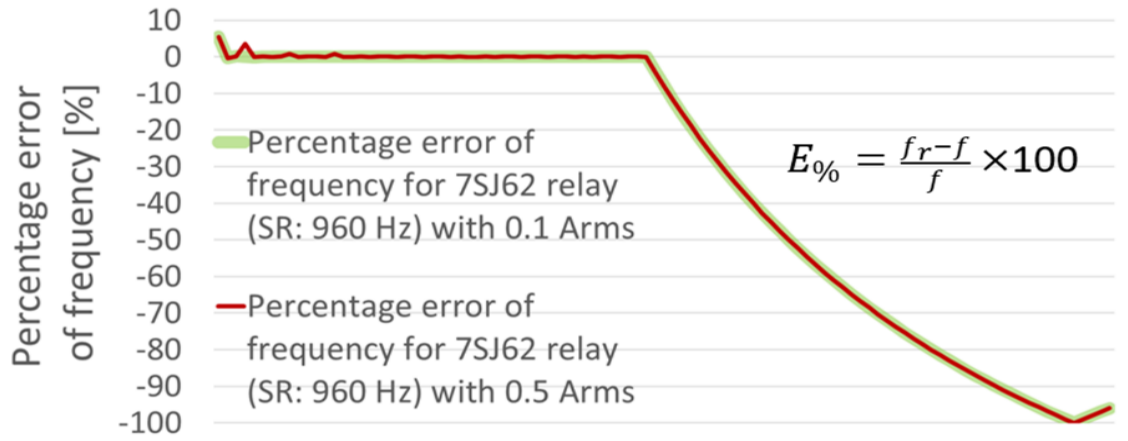

$E_{\%}=$ percentage error of frequency, $f_{r}=$ relay frequency, $f=$ source (real) frequency

Figure A.6. Percentage error of frequency response of 7SJ62 SIPROTEC relay. 


\section{APPENDIX B. CURRENT FREQUENCY ANALYSIS UP TO 20.16 kHZ}

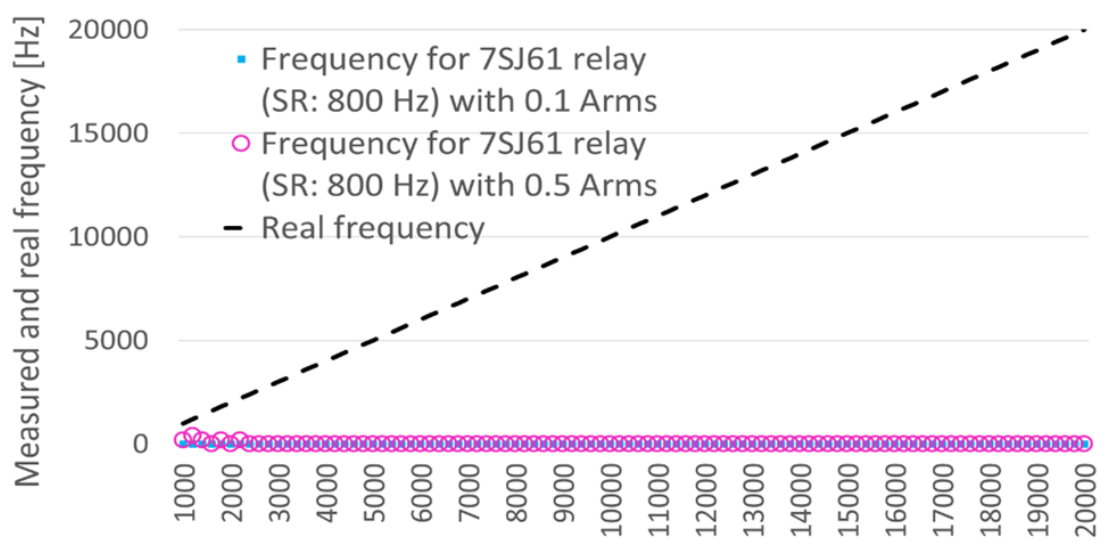

Source current frequency $[\mathrm{Hz}]$

Figure B.1. Measured frequency versus real (source) frequency of 7SJ61 SIPROTEC relay.

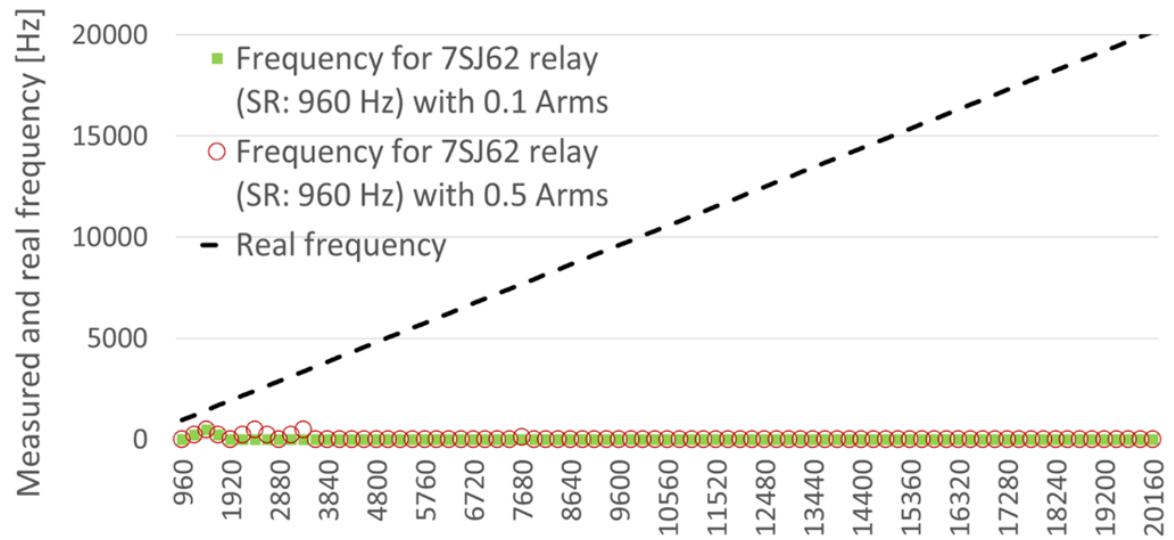

Source current frequency $[\mathrm{Hz}]$

Figure B.2. Measured frequency versus real (source) frequency of 7SJ62 SIPROTEC relay.

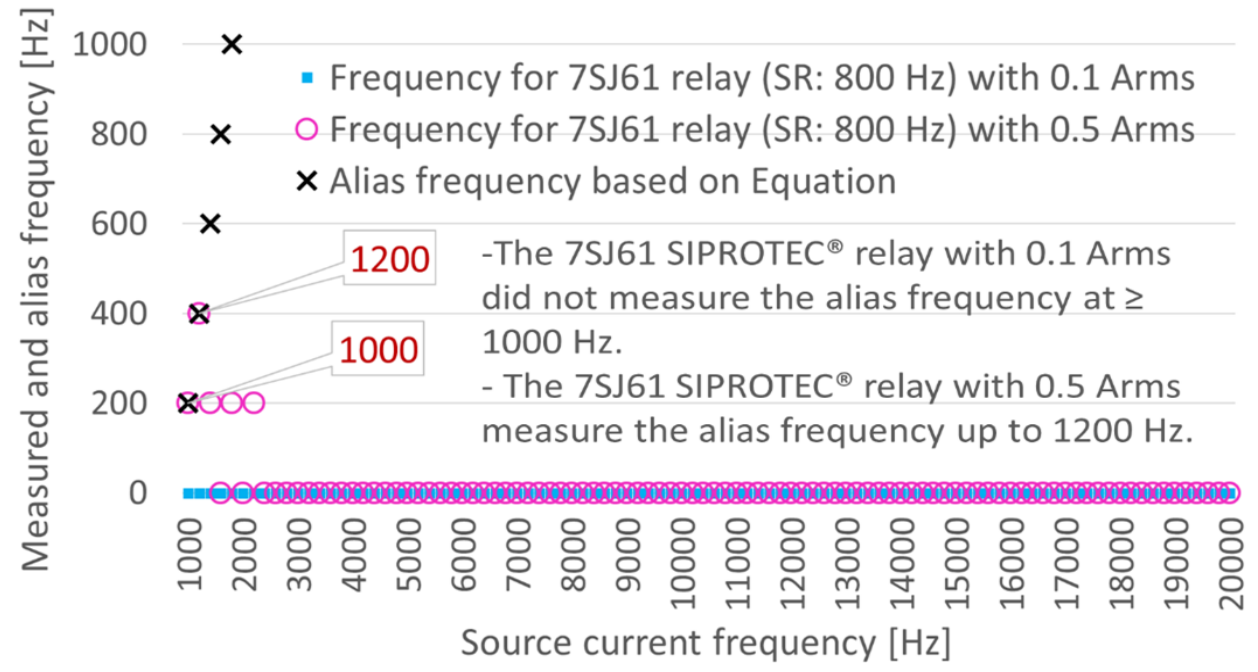

Figure B.3. Measured frequency versus alias frequency of 7SJ61 SIPROTEC relay. 


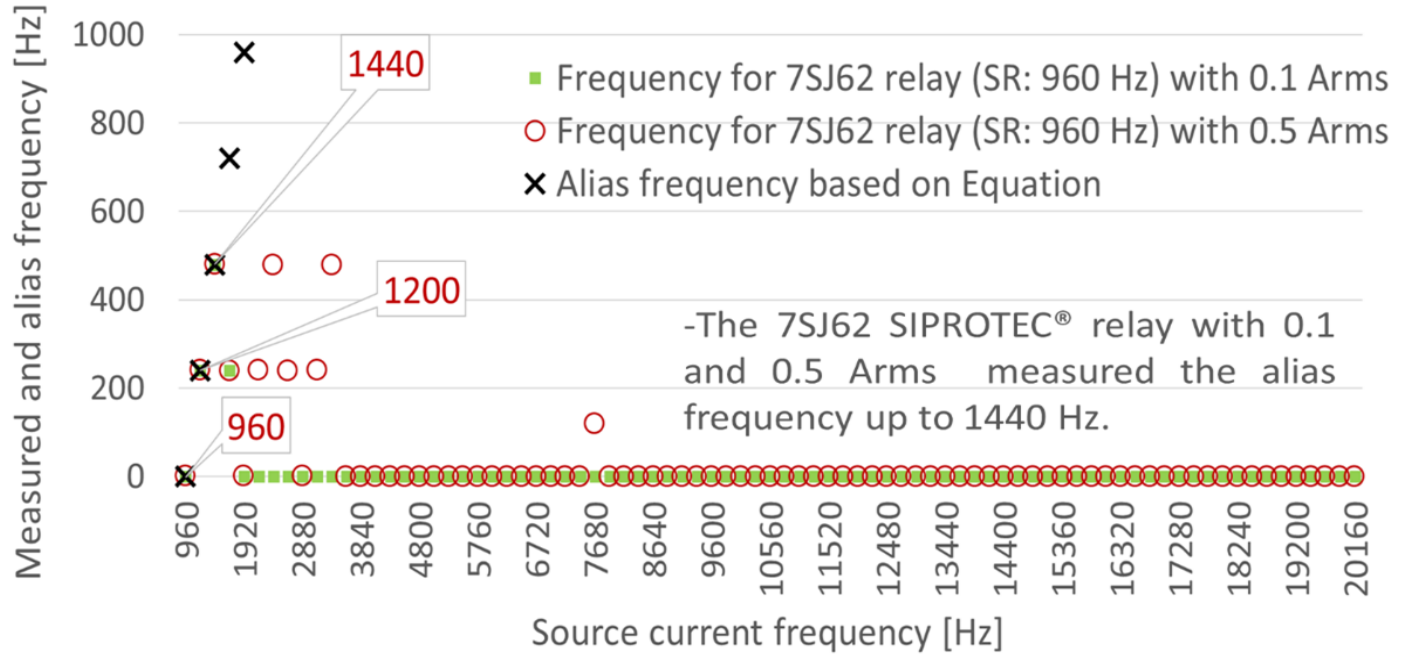

Figure B.4. Measured frequency versus alias frequency of 7SJ62 SIPROTEC relay. 


\section{APPENDIX C. CURRENT MAGNITUDE ANALYSIS UP TO 1 kHZ}

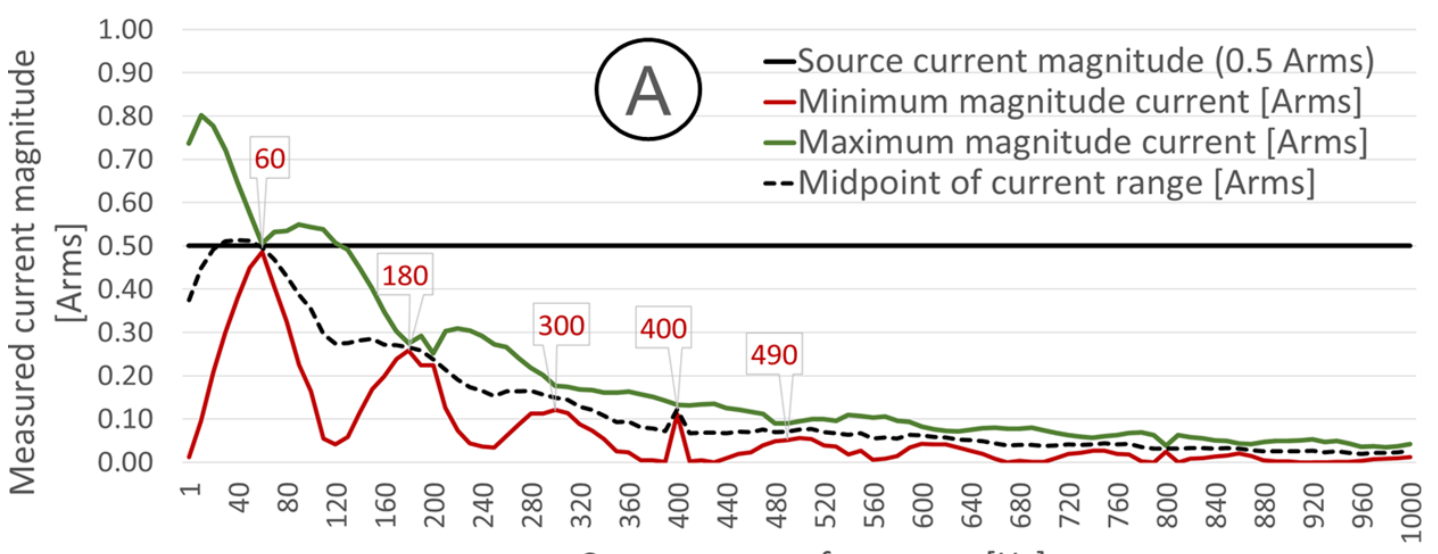

\section{Source current frequency $[\mathrm{Hz}]$}

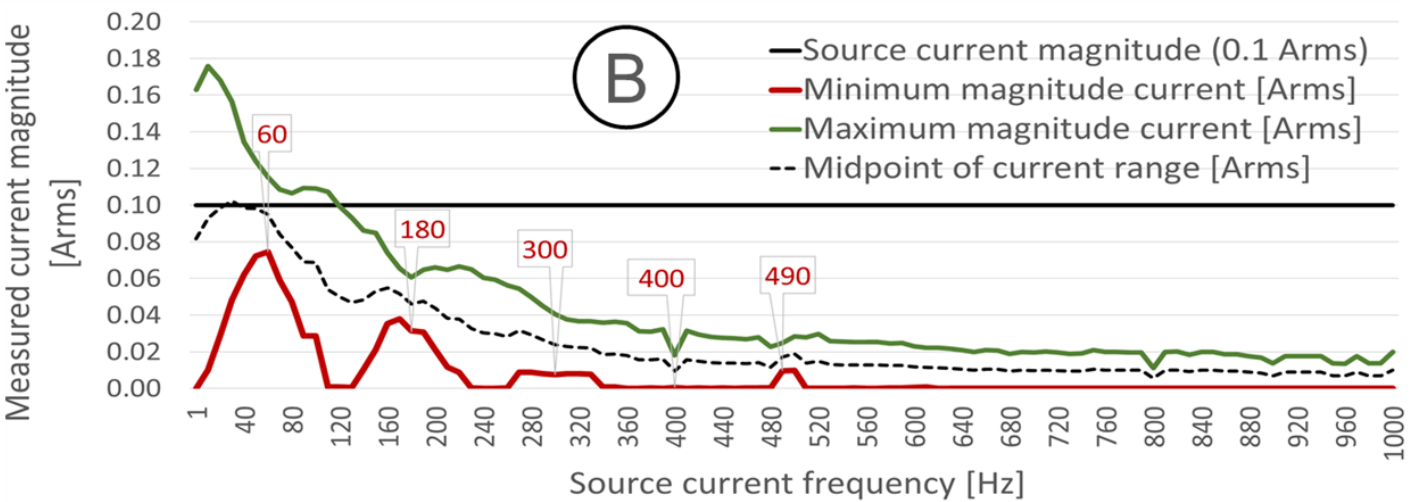

Figure C.1. Measured current magnitude at 0.5 (A) and 0.1 (B) Arms of 7SJ61 SIPROTEC relay.
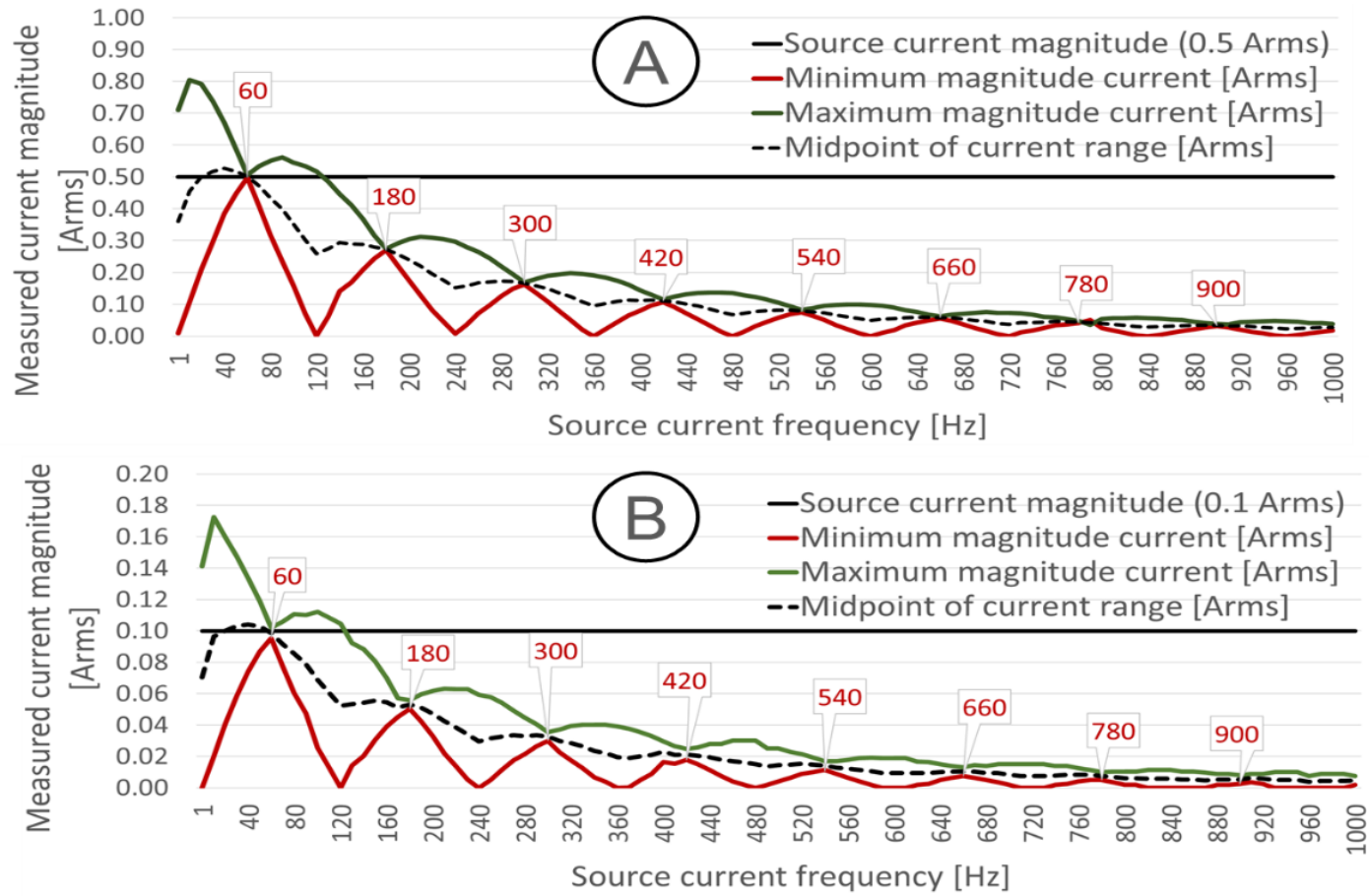

Figure C.2. Measured current magnitude at 0.5 (A) and 0.1 (B) Arms of 7SJ62 SIPROTEC relay. 
Source current frequency [Hz]

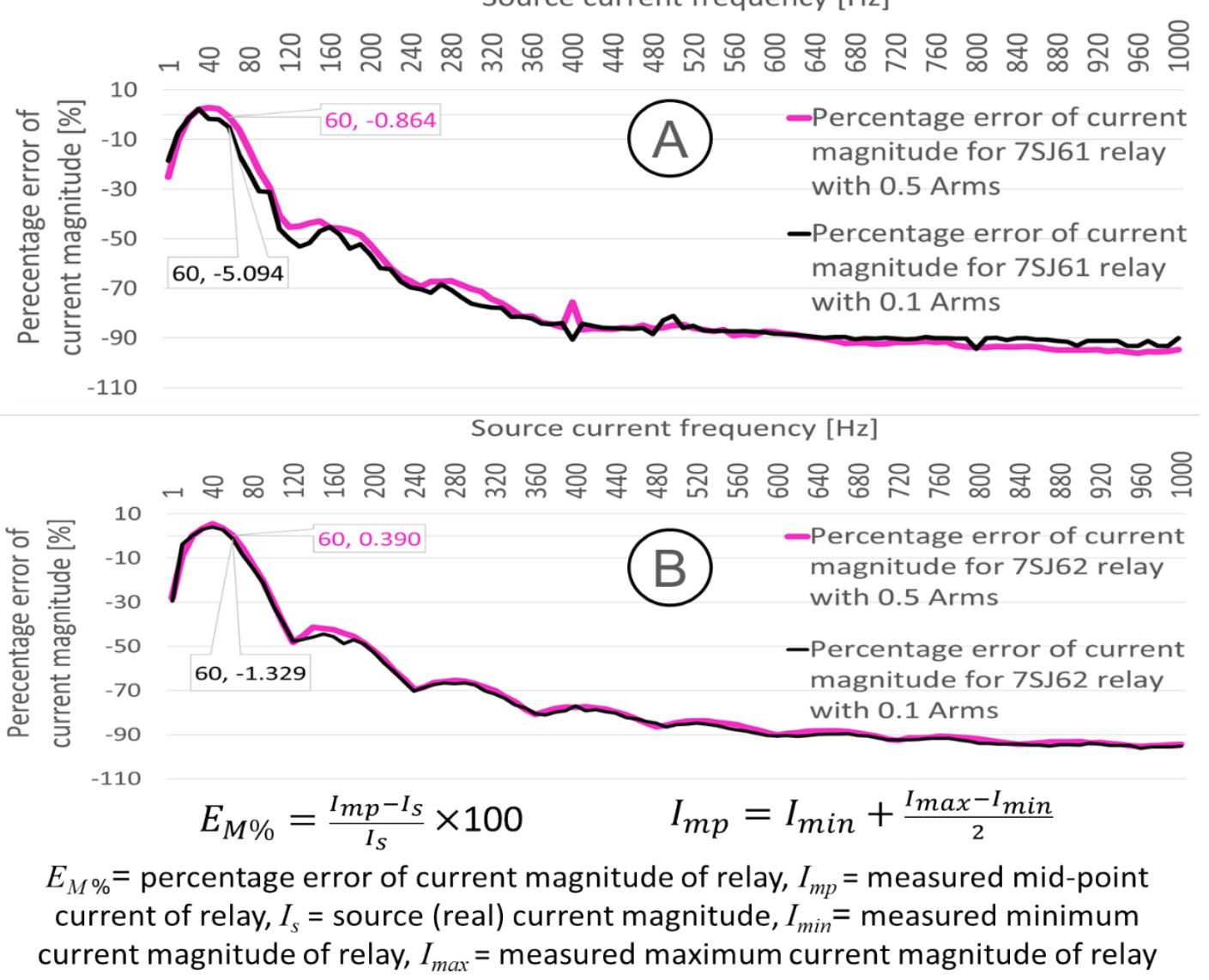

Figure C.3. Percentage error of current magnitude of 7SJ61 (A) and 7SJ62 (B) SIPROTEC relays. 


\section{APPENDIX D. CURRENT MAGNITUDE ANALYSIS UP TO 20.16 kHZ}

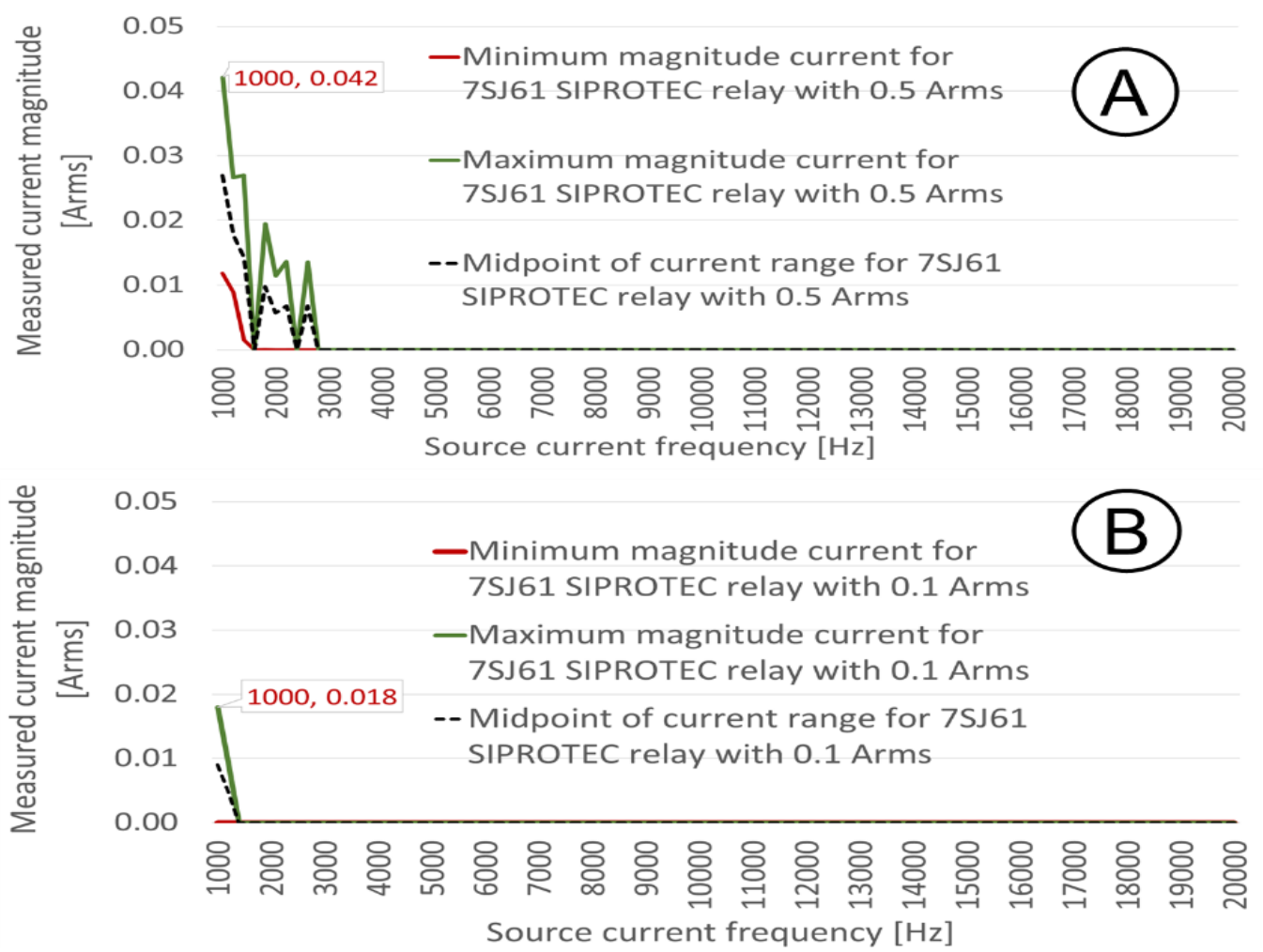

Figure D.1. Measured current magnitude at 0.5 (A) and 0.1 (B) Arms of 7SJ61 SIPROTEC relay.

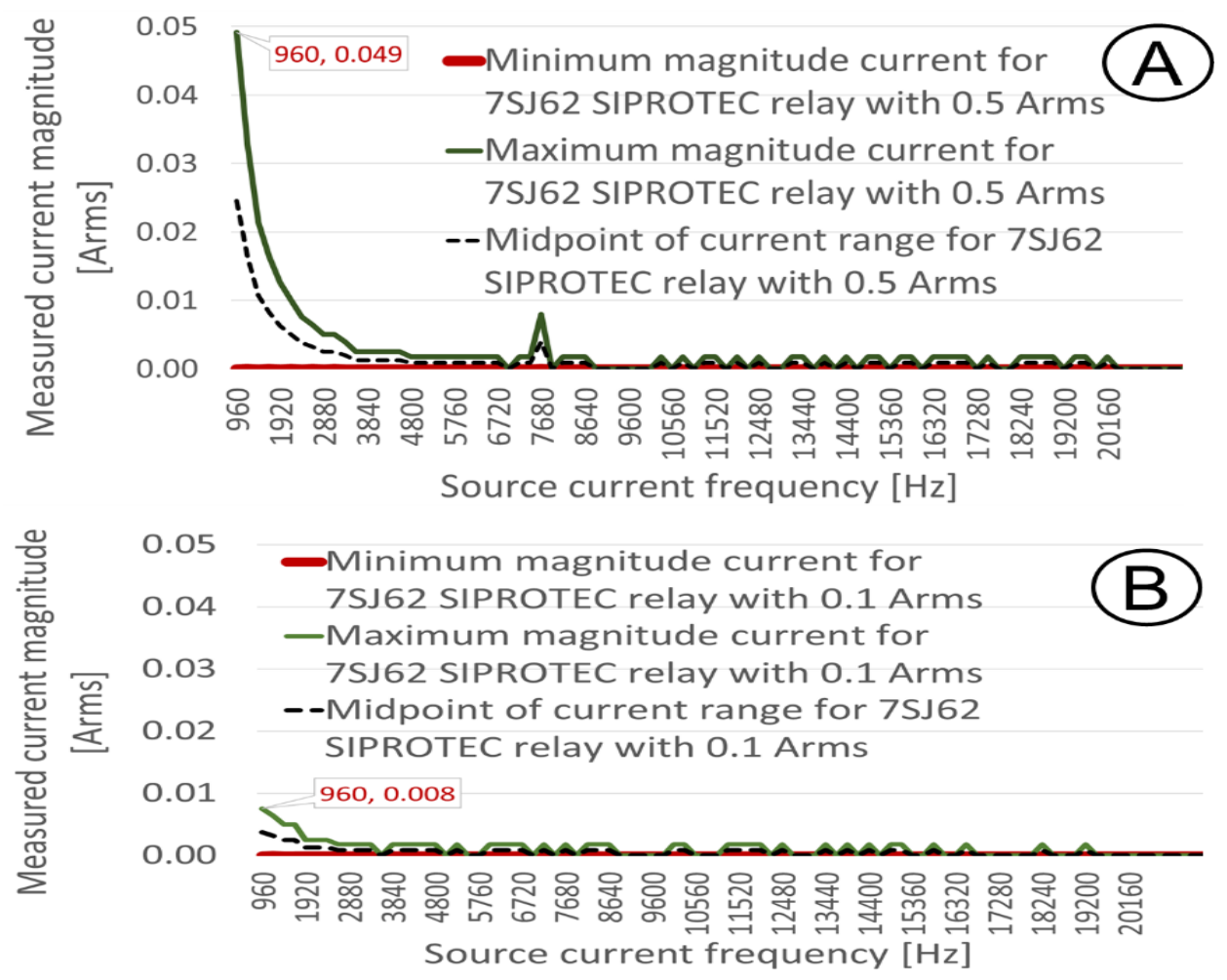

Figure D.2. Measured current magnitude at 0.5 (A) and 0.1 (B) Arms of 7SJ62 SIPROTEC relay. 


\section{APPENDIX E. CURRENT MAGNITUDE INTENSITY FROM 1 TO 20.16 kHZ}

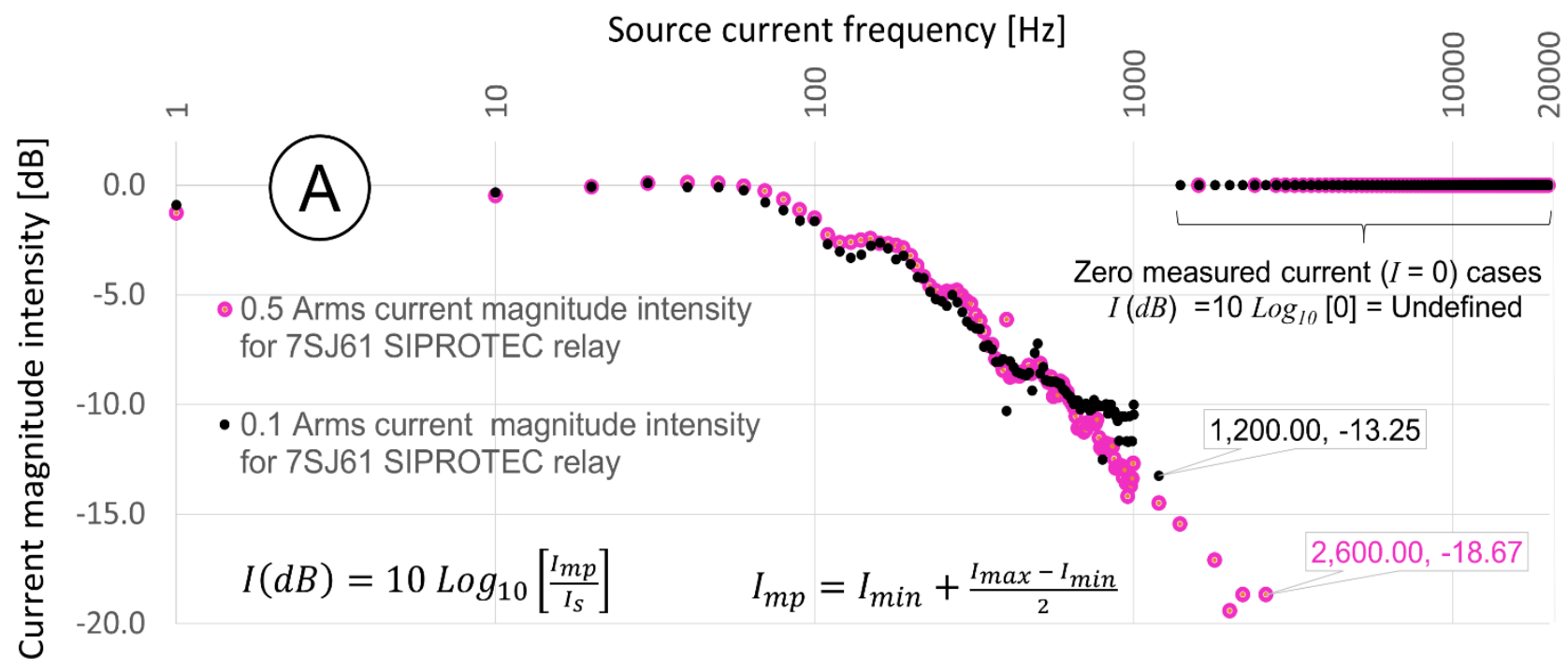

$I(d B)=$ current magnitude intensity in decibels, $I_{m p}=$ measured midpoint current magnitude of relay in Arms, $I_{s}=$ source (real) current magnitude in Arms, $I_{\min }=$ measured minimum current magnitude in Arms, $I_{\max }=$ measured maximum current magnitude in Arms

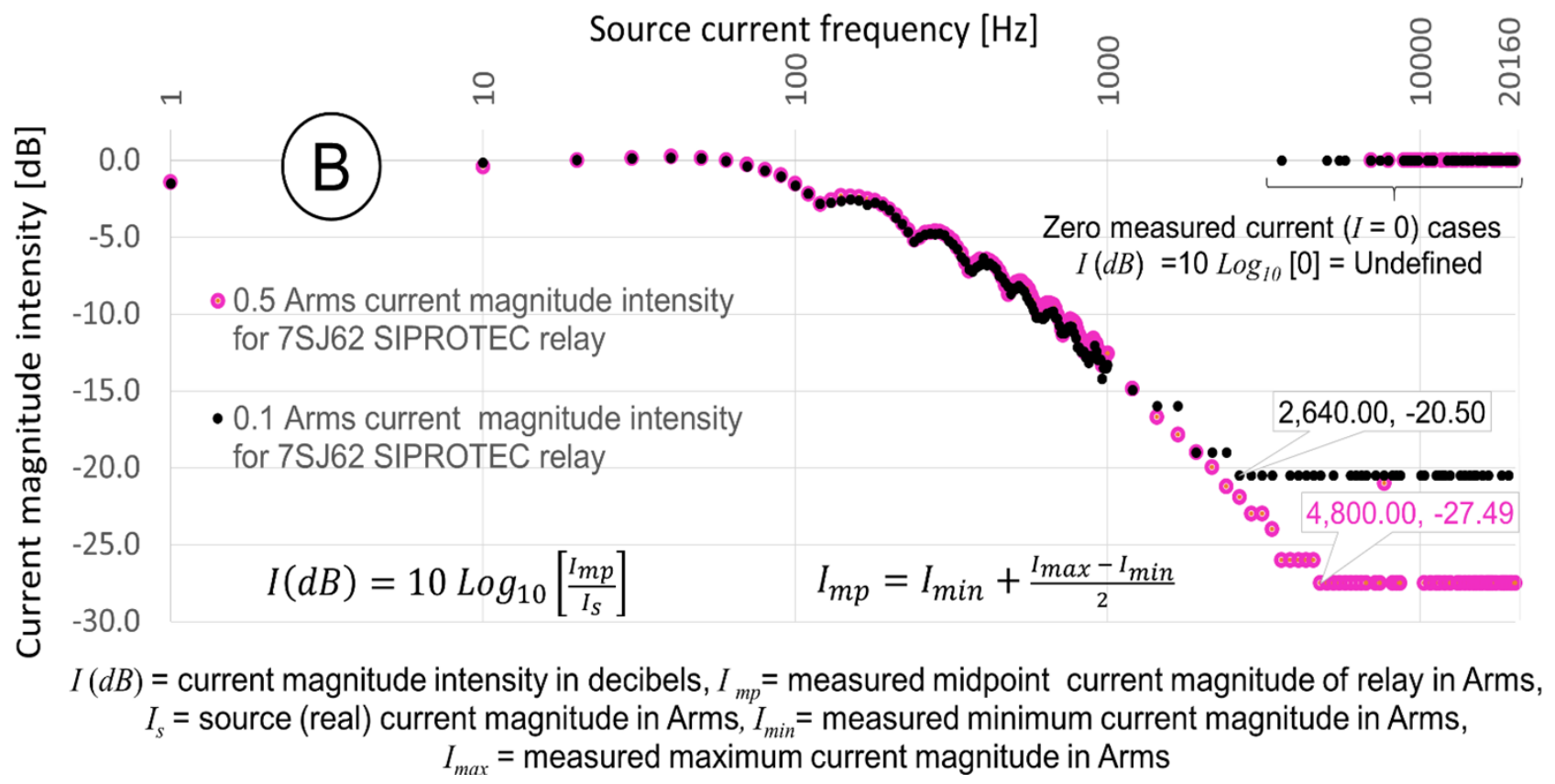

Figure E.1. Current magnitude intensity response of 7SJ61 (A) and 7SJ62 (B) SIPROTEC relays. 